\title{
KRITIK TERHADAP METODE MUHAMMAD AL-GHAZALI DALAM MEMAHAMI HADITS NABI MUHAMMAD SAW
}

\author{
Abdul Basid \\ Fakultas Ushuluddin INSTIKA Guluk-guluk Sumenep \\ Email: abdulbasid1982@gmail.com
}

\begin{abstract}
Abstrak:
Metode Muhammad al-Ghazali dalam memahami Hadits Nabi Muhammad Saw yaitu, Muhammad al-Ghazali tidak mau mempergunakan hadits âhâd dalam menetapkan akidah, masalah akidah harus berdasarkan keyakinan, dan bukan pada dugaan. sesuatu yang dhanni tidak layak untuk diamalkan dan dijadikan hukum, serta penelitian hadis pada kritik matan. kajian Muhammad al-Ghazali terhadap Hadits Nabi menitik beratkan pada kritik matan, dalam arti mengkaji otentisitas sebuah matan hadis dan mengungkap makna (memahami hadis Nabi).
\end{abstract}

Kata Kunci: Metode, Hadits

\section{Abstract:}

The method of Muhammad al-Ghazali in understanding the Hadith of Prophet Muhammad SAW, Muhammad al-Ghazali did not want to use the hadith of âhâd in determining aqidah, aqidah problem should be based on belief, and not on suspicion. something dhanni not worthy to be practiced and made law, and research hadith on criticism matan. Muhammad al-Ghazali's study of the Prophet's hadith emphasizes the criticism of matan, in the sense of examining the authenticity of a hadith matan and revealing the meaning (to understand the hadith of the Prophet)

Keywords: Method, Hadith

\section{Pendahuluan}

Keberadaan Hadits secara hirarkis-doktrinal menempati posisi kedua setelah al-Qur'an. Fungsinya sebagai perinci dan penjelas (bayan tafsil dan bayan tafsir) al-Qur'an ${ }^{1}$ sehingga perkembangan Hadits menjadi disiplin khusus untuk senantiasa

1 Muhammad Said Kaylani, al-Risalah al-Syafi'ie, (Mesir: Mustafa al-Babi alHalabim 1969), 21 
mendapatkan perhatian dan kajian khusus terkait dengan posisi tersebut sebagai sumber ajaran Islam. Dan banyak para tokoh intelektual islam mulai masa klasik hingga kontemporer menaruh simpati kepada disiplin khusus Hadits untuk melakukan kajian ilmiah dengan berbagai teori pendekatan yang mereka gunakan. Dan dari berbagai teori tersebut juga lahir bermacam disiplin keilmuan khususnya dibidang Hadits yang masuk dalam rumpun ilmu Hadits.

Disiplin ilmu yang secara teoritis mengkaji sumber ajaran Islam yang kedua ini sering kali dikenal dengan istilah "mushtalahul Hadits"dengan usaha-usaha yang lebih mendalam terkait dengan Hadits tersebut berdasarkan priodisasi perkembangan Hadits tersebut. Adapun tokoh pertama yang menulis tentang teori-teori tentang kajian teoritis Hadits ini adalah Muhammad Ibn Shihab al-Zuhri pada masa pemerintahan Umar Ibn Abdul Aziz. Al-Zuhri yang pertama kali menghimpun dan melakukan kodifikasi Hadits resmi atas perintah khalifah. Kemudian setelah itu, lahirlah ilmu yang khusus mengkaji tentang seputar Hadits dan periwayatannya yang dikenal dengan "Ilmu Musthalahul Hadits" yang dikarang oleh al-Hafidz Ibn Hajar dengan karyanya "Nuhbat al-Fikar fi Musthalah Ahl al-athar", 2 dan banyak yang lainnya.

Kemudian, seiring perkembangan waktu dan juga ilmu pengetahuan dan tekhnologi, berbagai metode telah diciptakan untuk mengurai makna dan maksud dari Hadits nabi Muhammad Saw, bahkan kajian-kajian telah juga dilakukan yang meliputi eksperimentasi seputar teks dan perawi Hadits, sehingga banyak ditelorkan karya-karya yang secara spesifik mengkaji tentang itu semua.

Beberapa tokoh modern dan kontemporer yang melakukan pengkajian dan penelitian terhadap Hadits adalah seperti Muhammad al-Ghazali, Ajjaj Khatib, Yusuf al-Qaradhwai, dan lain sebagainya. Masing-masing tokoh tersebut dengan ketelatenannya melahirkan karya-karya yang secara akademis memiliki signifikansi yang begitu terasa adanya, sehingga sampai saat ini, karya-karya mereka mendapatkan apresiasi besar dari kalangan intlektual maupun akademisi.

Makalah ini salah satunya yang akan melakukan telaah kritis terhadap salah satu tokoh yang disebutkan di atas, yaitu Muhammad al-Ghazali, sebagai salah satu tokoh yang begitu

\footnotetext{
2 Muhammad Alawi al-Maliki, Ilmu Ushul al-Hadith, (Yogyakarta: Pustaka Pelajar,
} 2012), 37-39 
berpengaruh dan mendapatkan perhatian besar di kalangan akademis dan intlektual tradisional yaitu para ulama'. Makalah ini dimaksudkan untuk mengetahui lebih mendalam tentang metode Muhammad al-Ghazali dalam memahami Hadits nabi Muhammad Saw, kemudian juga, penulis akan melakukan telaah kritis terhadap metode tersebut terkait dengan teori yang dimiliki oleh penulis.

\section{Biografi Muhammad Al-Ghazali}

Muhammad al-Ghazali lahir di kampung Naklah al-Inab, Itay al-Barud, Buhairah, Mesir, 22 September 1917. Tokoh yang diberi nama oleh ayahnya dengan Muhammad al-Ghazali ini, tumbuh sebagai penghafal al-Qur'an pada usia 10 tahun dibawah asuhan ayahnya yang juga hafal al-Qur'an. Ia diberi nama al-Ghazali karena ayahnya sangat cenderung dengan profil Imam Abu Hamid alGhazali (penulis kitab al-Ihyâ' ulumuddin) dan sangat terobsesi dengan pikiran tasawufnya. ${ }^{3}$ Awal pendidikan al-Ghazali diterima di kota Iskandariyah dari tingkat dasar hingga menengah, kemudian pindah ke Kairo melanjutkan kuliah di Fakultas Ushuluddin. Setelah lulus tahun 1361 H 1943 M, ia mengambil spesialisasi Dakwah Wa al-Irsyâd dan mendapt gelar Magister pada 1362 H/1943 M. Para guru yang sangat berpengaruh saat ia studi adalah; Syeikh Abdul Aziz Bilal, Syeikh Ibrahim al-Gharbawi, Syeikh Abdul 'Azhim Az-Zarqani, dan lain-lain. Atau menurut apa yang ia sendiri katakan, al-Ghazali mengomentari tentang dirinya; "Jika Imam alGhazali terpengaruh dengan otak para filusuf dan Ibnu Taimiyah terpengaruh degan otak ahli fiqih, maka saya menganggap diri saya adalah murid dari sekolah filsafat dan fiqih dalam waktu yang sama. Saya sangat dipengaruhi oleh Syeikh Abdul Azim Az-Zarqani dan Muhammad Saltut, akan tetapi saya lebih dipengaruhi oleh Hasan al-Banna"4.

\section{Latar Belakang Pendidikan Muhammad Al-Ghazali}

Pendidikan dasar Muhammad al-Ghazali dimulai dari madrasah di desanya, di situlah ia menghafalkan al-Qur'an 30 juz. Setelah itu ia masuk sekolah Agama Ibtida'iyyah di Iskandariyah selama tiga tahun dan memperoleh ijazah persamaan. Kemudian meneruskan pendidikan Tsanawiyah selama dua tahun dan lulus pada tahun 1937 M. Setelah itu ia melanjutkan kuliah di Fakultas

\footnotetext{
3 Zaenal Abidin Suamsuddin, Ensiklopedi Penghujatan Terhadap Sunnah, (Jakarta: Pustaka Imam Abu Hanifah, 2007), 265

4 Muhammad Sa'id Myrsi, 'Adzoma' al Islâm, terj. Khoirul Amru, ( Pustaka Al Kautsar, 2007), 329-330
} 
Universitas al-Azhar dan mendapatkan gelar pada tahun 1943 M. Ia memperoleh gelar magister dari Fakultas Bahasa Arab di Universitas yang sama. ${ }^{5}$

Setelah lulus dari Universitas al-Azhar, aktifitas Muhammad al-Ghazali selain bayak berkecipung dalam bidang dakwah, juga banyak menggeluti dunia pendidikan dan kebudayaan. Adapun aktifitas Muhammad al-Ghazali selama di Mesir antara lain: tahun 1943, ia ditunjuk sebagai Imam dan Khatib pada Masjid al-Utba' alKhadra di Kairo. Muhammad al-Ghazali juga pernah menjabat sebagai wakil kementerian Wakaf dan Urusan Mesir. Di Universitas al-Azhar, Syeikh Muhamad al-Ghazali mengajar di Fakultas Syari'ah, Ushuluddin, Dirasah al-Arabiyah wa al-Islamiyyah dan Fakultas Tarbiyah. Pada tahun 1988, pemerintah Mesir menganugerahkan bintang kehormatan tertinggi kepada Muhammad al-Ghazali dalam bidang pengabdian kepada Islam. ${ }^{6}$

Semasa kuliah ia direkrut oleh Syeikh Hasan al-Banna (pendiri al-Ikhwan al-Muslimîn). Hingga menjadi seorang anggota, tokoh, dan terkenal sebagai juru bicara Ikhwân al-Muslimîn yang paling jujur. Semasa hayatnya, ia pernah menjadi penasihat dan pembimbing di Kementrian Wakaf, ketua Dewan Kontrol Masjid, Ketua Dewan Da'wah, dan terakhir menjadi Wakil Menteri Wakaf dan Urusan Dakwah Mesir. Selain itu Muhammad al-Ghazali juga menjadi guru besar disejumlah Universitas seperti al-Azhar (Mesir), Ummul Qura (Makkah), King Abdul Aziz (Jeddah), Qathar, dan al-Jazair. Karya tulis yang dihasilkannya lebih dari 60 buah buku dari sudut pandang pemikiran, Syari'at dan Akhlaq. ${ }^{7}$

Aktivitas di luar Mesir, antara lain di Saudi Arabiah. Dia berdakwah dan memberikan ceramah melalui radio, televisi dan menulis di berbagai majalah dan surat kabar. Di samping itu, ia juga memberikan kulian di Universitas Umm al-Qura (Mekkah) Saudi Arabiah. Muhammad al-Ghazali adalah orang Mesir pertama yang mendapat penghargaan Internasional Raja Faishal dan kerajaan Saudi Arabiah. Muhammad al-Ghazali juga banyak menghabiskan waktu hidupnya di Qatar. Bahkan beliau mempunyai peran yang besar dalam merealisasikan Fakultas Syari'ah di Universitas setempat, dan pernah diangkat sebagai guru besar di Fakultas tersebut.

\footnotetext{
${ }^{5}$ Abd al-halim Uwais, SyeikhMuhammad al-Ghazal, Marahil Azimmmah, (Kairo: al-Shahwah, 1993), 15.

${ }^{6}$ Yusuf Al Qardhawi, Syeikh Al Gazali Kamâ 'Araftuhu, (Beirut: Dâr Syurûq, 2000), 26

${ }^{7}$ Heri Sucipto, Ensiklopedi Tokoh Islam, (Bandung: Hikmah, 2003), 341
} 
Pada setiap bulan Ramadhan, Muhammad al-Ghazali sering diundang pemerintah Kuwait untuk mengisi kegiatan keagamaan. Muhammad al-Ghazali juga sering diundang sebagai pembicara utama dalam seminar-seminar pemuda dan mahasiswa di Amerika maupun di Eropa.Selama kurang lebih delapan tahun, Muhammad al-Ghazali menjadi tenaga pengajar di Universitas Amir 'Abd alQadir al-Jailani. Ia memberikan kontribusi yang cukup besar dengan jasa-jasanya, pemerintah al-Jazair menganugerahkan penghargaan al-Atsir, bintang kehormatan tertinggi di-Aljazair, dalam bidang dakwah Islam. ${ }^{8}$

Al-Ghazali memang dikenal temperamen, kemarahannya cepat meluap, ini karena kebenciannya yang sangat pada kezaliman dan kehinaan. Baik hal itu ada pada dirinya atau orang lain. Yusuf al-Qaradhawi mengatakan; " Mungkin anda berbeda pandangan dengan al-Ghazali, atau ia berbeda pendapat dengan anda dalam masalah-masalah kecil atau besar, sedikit atau banyak masalah. Tapi apabila anda mengenalnya dengan baik, anda pasti mencintai dan menghormatinya. Karena anda tahu keikhlasan dan ketundukannya pada kebenaran, keistiqomahan orientasi dan ghirahnya yang murni untuk Islam. ${ }^{9}$

Mengenai ketegasannya dalam bersikap, pernyataan kafir atas Faraj Faudah yang telah menghina Islam adalah buktinya.Tentang kedudukan Faraj Faudah, al-Ghazali pernah dipanggil oleh Mahkamah Negara Mesir untuk ditanyai tentang beberapa perkara menyangkut hukum Islam dalam Negara, dan kedudukan orang-orang yang berlepas diri dari hukum Islam, baik karena bercanda atau kesungguhannya. Mengisahkan cerita tersebut dalam sub judul As-Sahâdah fi Muqtali Faraj Faudah bahwa Muhammad al-Ghazali berpendapat bahwa wajib hukumnya menegakkan hukum Islam dalam tubuh sebuah Negara, dan orangorang yang menolaknya baik ia bercanda maupun ia sungguhsungguh dalam hal itu, maka ia keluar dari millah (murtad).10

Ketokohan al-Ghazali kemudian menjadi banyak rujukan dimana-mana. Sejumlah buku yang ia karang tidak hanya membangkitkan semangat kaum muslimin dalam melawan penjajahan barat dan kebusukan hati orang-orang Yahudi, namun juga membuahkan kritik. Kritik-kritik tersebut datang dari

8 Suryadi, metode kontemporer memahami Hadits Nabi, (Yogyakarta: Teras, 2008), 26

9 Hendri Mohammad, Tokoh-tokoh Islam yang Berpengaruh Abad 20, (Jakarta: Gema Insani Press, 2006), 236

10 Yusuf Al-Qardhawi, Syeikh al-Ghazali Kamâ 'Araftuhu, (Beirut: Dâr Syurûq, 2000), 280-283 
sejumlah tokoh-tokoh pergerakan da'wah yang menganggap pendapat-pendapat al-Ghazali mengenai hadits banyak yang bertentangan dengan apa yang telah dijelaskan oleh jumhur para ulama ahli sunnah (salaf al-sholih).

\section{Aktifitas Muhammad Al-Ghazali}

Muhammad al-Ghazali adalah seorang dâ'i dan penulis yang disegani di dunia Islam, khususnya di timur tengah. Tempattempatnya seperti masjid selalu dipadati oleh ulama, kaum cendikiawan, pelajar dan segenap lapisan masyarakat lainnya. Walaupun bergabung dan aktif di gerakan Ikhwan al Muslimin, ia secara tegas menyatakan bahwa kepentingan Islam di atas kepentingan lainya, menurutnya, seandainya kepentingan Ikhwan al Muslimîn harus dibuang jauh-jauh. ${ }^{11}$ Pertama kali Muhammad alGhazali dengan Hasan al-Banna (1906-1949), ketika masih sekolah di tingkat akhir Sekolah Tsanawiya di Iskandaria, tepatnya pada tahun 1935 M. di Masjid Abd al-Rahman bin Harmuz ketika Hasan al-Banna menyampaian dakwah atau ceramah. Perkenalan itu semakin intensif ketika Muhammad al-Ghazali kuliah di al-Azhar, Kairo, dan direktur oleh Imam Hasan al-Banna untuk menjadi anggota Ikhwan al-Muslimîn. ${ }^{12}$ Bahkan selanjutnya menjadi salah seorang tokoh Ikhwan al-Muslimîn. Bagi Muhammad al-Ghazali, Hasan al-Banna adalah guru yang telah mengajarkan kepada hakikat Islam yang hidup dan mati. Walaupun Muhammad alGhazali aktif di gerakan al-Ikhwan al-Muslimîn, serta kagum pada seorang sosok Hasan al-Banna, namun kekagumanya tidak sampai pada taraf pengkultusan ${ }^{13}$.

Muhammad al-Ghazali menetap di Saudi Arabiah selama tujuh tahun. Di sana ia aktif dalam kegiatan dakwah, di antaranya mengisi ceramah harian melalui radio, acara dakwah di televisi, dan menulis beberapa majalah dan surat kabar. Di samping itu, ia

${ }^{11}$ Abd al-Halim 'Uwais, al-Syeikh Muhammadal-Ghazali, 18

12 Al-Ikhwan al-Muslimin didirikan pada bulan Maret 1928 oleh Hasan al-Banna (1906-1949). Organisasi ini pada mulanya merupakan gerakan dakwa, meningkat menjadi gerakan polotik delam rangka menghadapi invensi Inggris, dengan motto perjuangannya: Al-Qur'an sebagai dasar, Rasulullah sebagai teladan, jihad sebagai jalanperjuangan dan syahid sebagai cita-cita hidup serta islam sebagai ajaran tertulis. Al-Ikhwan al-Muslimin juga mrupakan gerakan Islam modern, sekaligus juga sebagai pusan pembaruan ke-Islam-an dan aktifitas Islam sudah jatuhnya Khalifah yang menyebabkan umat terpecah ke dalam beberapa kelopok. Lihat Yusuf Qardhawi, al-Syeikh al-Ghazali, 7; .

13 Ibid, 19 
juga memberikan kuliah di Universitas Ummul Qura. Muhammad al-Ghazali tinggal di Qatar selama enam bulan dalam setahun. Ia mempunyai peran besar dalam mewujudkan Fakultas Syariah di universitas setempat, di samping itu ia aktif dalam memberikan bimbingan Islam di televisi, radio, masjid-masjid dan tempattempat lainnya di Qatar. Di Qatar, ia diperlakukan sebagai tamu Negara dan mendapatkan perlakuan istimewa. Dalam beberapa hal, pemerintah Qatar meminta pendapatnya untuk memutuskan kebijaksanaan. Demikian juga di Kuwait, pemerintah setiap tahunnya pada bulan Ramadhan mengundangnya untuk mengisi kegiatan-kegiatan keagamaan yang dihadiri beberapa pejabat tinggi Negara, di antarnya menteri Wakaf Kuwait. Sementar di Eropa dan Amerika, Muhammad al-Gazali sering diundang sebagai pembicara utama dalam seminar-seminar pemuda dan mahasiswa. Dalam setiap kesempatan, perannya sangat menentukan dalam keberhasilan seminar-seminar tersebut. Muhammad al-Ghazali juga pernah berjuang selama delapan tahun di Aljazair. Jasanya banyak dikenang di Aljazair, karena ialah yang mengembangkannya beberapa fakultas di Universitas Qusnathinah yang dulunya hanya memiliki satu fakultas dan kemudian menjadi enam fakultas yang tesebar di Aljazair. Pemerintah Mesir pada tahun 1988 menganugerahkan bintang kehormatan tertinggi kepada Muhammad al-Ghazali. Demikian juga dengan pemerintah Aljazair yang telah menganugerahkan kepadanya medali al-Atsir bintang kehormatan tertinggi di Aljazair dalam bidang dakwah Islam. Dan dialah orang mesir pertama yang mendapat penghargaan internasional Raja Faishal dari kerajaan Saudi Arabiah dalam bidang pengabdian kepada Islam.14

Dua obyek sasaran dakwah Muhammad al-Ghazali adalah: pertama, musuh-musuh yang membenci dan memerangi Islam, yakni, Zionisme, kaum Kristen dan Komonisme. Walaupun mareka berbeda keyakinan, mereka bersatu untuk menghancurkan Islam. Kedua, umat Islam yang tidak mengatahui hakikat Islam, tetapi mengklaim sebagai seorang yang ahli. Menurut Muhammad alGhazali kelompok ini lebih berbahaya dari kelompok pertama, Karena mereka sering memecah belah umat Islam dengan membesarkan masalah-masalah khilafiyyah.15

Muhammad al-Ghazali meninggal akibat serangan jantung kronis dengan pembekuan darah yang sudah lama dideritanya.

14 Terjemah dari kitab Kaifa Nata'amal ma'a al-Qur'an, (Mizan: 1991), 7.

15 Syeikh Muhammad al-Ghazali, berdialog, "Syeikh Muhammad al-Ghazali di mata Yusuf Qardhawi", 1-4. 
Para dokter sebenarnya telah menasihati untuk mengurangi aktifitasnya, karena kondisi kesehatannya itu, tetapi nasehat itu tidak dihiraukan. Bahkan beberapa bulan menjelang akhir hayatnya, Muhammad al-Ghazali masih sempat mengunjungi Amerika Serikat mewakili markas penelitian ilmu-ilmu keislaman di Mesir. Setelah itu ia menghadiri Festival kebudayaan di Janadriyah Riyadh.

Pada hari Sabtu tanggal 19 Syawwal $1416 \mathrm{H}$ bertepatan dengan 9 Maret 1996, dunia Islam dikejutkan dengan meninggalnya Muhammad al-Ghazali di Riyadh, ketika sedang memberikan ceramah dan menghadiri seminar "Islam dan Barat"di Riyadh Saudi Arabiah.16Jenazahnya dipindah ke Madinah alMunawarah untuk dimakamkan di al-baqi'. Dengan berpulangnya Muhammad al-Ghazali kepangkuan Ilahî Robbî, umat Islam kehilangan tokoh pemikir dan da'î terkemuka. Ia wafat pada usia 78 tahun. Atas kegigihan Muhammad al-Ghazali inilah, Yusuf alQaradhawi menganggapnya sebagai syahid, karena ia meninggal dalam keadaan berdakwah dan membela Islam. ${ }^{17}$

\section{Karya-karya Muhammad Al-Ghazali}

Muhammad al-Ghazali mewariskan enam puluh buku lebih dalam berbagai tema, plus ceramah, seminar, khutbah, nasihat, kajian dan dialog yang disampaikan di Mesir maupun di luar Mesir. Khutbah yang ia sampaikan di jami' al-Azhar, Amr bin al-Ash, dan khutbah Ied di lapangan Abidin serta jami' Mahmud punya arti dan pengaruh sangat besar, sebab dihadiri ribuan pendengar, sebagian bukunya telah dicetak ulang sampai dua puluh kali, dan sebagiannya telah diterjemah ke dalam pelbagai bahasa, serta sebagian telah dijadikan referensi pada sebagian universitas, seperti Fikihal-Sirah. Di antara buku pertama yang ia tulis ketika masih berusia muda adalah al-Islam wa al-Audha' al-Iqtisâdiyyah (Islam dan kondisi ekonomi) yang terbit pada tahun 1947. Dalam buku tersebut ia sangat tajam menyoroti perekonomian umat Islam dan mengkritik dengan pedas para penguasa yang hidup dalam bergelimpangan harta, sedangkan rakyatnya hidup dalam kemiskinan dan penderitaan. ${ }^{18}$

Diantara buku-buku karya Muhammad Al Ghazali adalah:

1. Al-Islâm wa al-Audla'ûl Iqtishâdiyah

\footnotetext{
${ }^{16}$ Faith Hasan Malkawi, al-'Atha'al-fikrli Syeikh Muhammad al-Ghazali, (Amman, 1996), 1.

17 Ibid.

18 Maskur Hakim, Berialog dengan al-Qur'an, ( Mizan, Bandung, 1996), 8.
} 
2. Al-Islâm wa al-Manhajjûl Isytirakiyah

3. Minhunâ Na'lâm

4. Al-Islâm wa al-Istibdadu al-Siyasi

5. Aqidat al-Muslim

6. Fiqhus Sirah

7. Zhalamun min al-Gharb

8. Qadza-iful Haq

9. Hashad al-Ghurur

10. Jaddid Hayatak

11. Al-Haqqul Murr

12. Rakâ-izul Iman bainal 'Aqli wal Qalb

13. At-Ta'ashub wat Tasamuh bainal Masihiyah wa al-Islâm

14. Ma'allâh

15. Jihadu al Da'wah baina 'Ajzid Fakhil wa Kaidil Kharij

16. Ath Thariqu min Hunâ

17. Al-Mahawîr al-Khamsah li al-Qur'an al-Karîm

18. Ad-Da'watul Islâmiyâh Tastaqbilu Qarnahâl Khamis 'Asyâr

19. Dusturul Wihdâdits Tsaqafiyah li al-Muslimîn

20. Al-Janib al 'Athifi min al-Islâm

21. Qadloya al-Mar'ah bainat Taqâlid al Rakidah wa al-Wafidah

22. As-Sunnatu al Nabawîyah baina Ahlil Fiqhi wa Ahlil Hadits

23. Musykilatun fi Tharîq al-Hayat al-Islâmiyah

24. Sirru Ta'akhirul 'Arabi Wa al-Muslimin

25. Kifahuddin

26. Hadza Dinunâ

27. Al-Islâm fi Wajhiz Zahwil Ahmar

28. 'Ilalun wa Adwiyah

29. Shaihat al-Tahdzirin min Du'atit Tanshîr

30. Ma'rakat al-Mushaf fil 'Alamil Islâmî

31. Humumu Da'iyâh

32. Miatu Sulain 'an al-Islâm

33. Khuthabun fi Syu'unid Din wa al-Hayah (5 Jilid)

34. Al-Ghazwul Fikri Yamtaddu fi Faraghinâ

35. Kaifa Nata'amal ma'al Qur'an al Karim

36. Mustaqbal al-Islâm Khariju Ardlihi, Kaifa Nufakkir Fihi?

37. Nahwa Tafsirin Maudlu'il Suwar al-Qur'an al-Karîm

38. Min Khunuzis Sunnah

39. Taamulat fi al-Dîn wal Hayâh

40. Al-Islam Al-Muftara 'Alaihi bainasy Syuyu'iyin war Ra'simaliyîn

41. Kaifa Nafhamul Islâm?

42. Turatsunal Fikri fi Mizanisy Syar'I wal 'Aqli

43. Qishshatu Hayâh

44. Waqi'ul 'Alamil Islami fi Mathla'il Qarnil Khamis 'Asyar 
45. Fannuda Dzikri wa al Du'a 'Inda Khatimil Anbiyâ'

46. Haqiqatul Qaumiyatil 'Arabiyah wa Usthuratil Ba'Tsil 'Arabi

47. Difa'un 'anil 'Aqidati wa al Syari'ah Dliddu Matha'inil Mustasyriqîn

48. Al-Islâm wath Thaqatul Mu'aththalah

49. Al-Isti'mâr Ahqadun wa Athma'

50. Huququl Insân baina Ta'alamil Islâm wa I'lanil Umamil Muttahidah

51. Nadlaratun fil Qur'an

52. Laisa minal Islâm

53. Fi Maukibid Dakwah

54. Khuluqul Muslim

Sebagian besar buku-buku beliau telah diterjemahkan ke beberapa bahasa, antara lain: bahasa Inggris, Turki, Perancis, Urdu, Indonesia dan lain sebagainya. Mayoritas penerjemah adalah murid-murid Muhammad al-Ghazali, pengagum dan orang-orang yang mendapat manfaat dari curahan ilmunya. Menurut Yusuf Qardhawi, buku-buku dan artikel Muhammad al-Ghazali pada masa mudanya sangat keras dalam memerangi kezaliman dan tirani. Banyak pemuda pada saat itu menghafal dan mengulang kata-kata Muhammad al-Ghazali. Yusuf Qardhawi teringat kepada al-Akh Abd Allah al-Uqail (mantan wakil sekretaris jendral Rabithah al-'Alam al-Islam) yang saat itu belajar di Fakultas Syari'ah Universitas alAzhar tahun 1950-an, yang menghafal di luar kepala Muqaddimah karya Muhammad al-Ghazali al-Islam wal Audh' al-Iqtishâdiyyah. ${ }^{19}$

Adapun dari sekian karya Muhammad al-Ghazali yang mengkaji masalah hadits dan Ulumul hadits secara mendalam adalah kitab al-Sunnah al-Nabawiyyah baina Ahl al-Fiqh wa Ahl alHadits, yang menjadi fokus kajian tulisan ini. Oleh sebab itu perlu diberi penjelasan agak lebar mengenai karya tersebut, karna, buku ini menimbulkan kontroversi dan kecaman dari beberapa orang yang menyoroti kitab tersebut. Bahkan sebagian kalangan menuduh Muhammad al-Ghazali sebagai penentang As-Sunnah dan ini merupakn tuduhan yang paling menyakitkannya. Tentusaja tuduhan ini sangat jauh dari kenyataan, kaerana ia adalah termasuk orang yang paling gigih dalam membela As-Sunnah. ${ }^{20}$

\section{Metode Muhammad al-Ghazali Dalam Memahami Hadits Nabi}

\footnotetext{
${ }^{19}$ Yusuf Qardhawi, al-Syeikh Muhammad al-Ghazali, 21.

20 Ibid, 9
} 
Muhammad al-Ghazali merupakan salah satu ulama kebangkitan Islam di Mesir yang membela eksistensi Hadits disamping al-Qur'an. Namun ada beberapa ulama yang lain menuduhnya sebagai pengingkar sunnah.

Dalam rangka pembelaannya terhadap sunnah atau Hadits Nabi SAW, al-Ghazali menulis buku as-Sunnah an-Nabawiyyah bainaahl al-Fiqh wa ahl al-Hadits. Buku ini mengetengahkan banyak tema sentral dalam diskusi muslim modern tentang hubungan antara al-Qur'an dan Hadits, posisi otoritas Nabi SAW, Kapasitas Nabi Muhammad tidak hanya hidup sebagai Rasul, Beliau juga menjadi seorang pemimpin masyarakat, bahkan kemudian menjadi pemimpin negara. Beliau menjalankan roda pemerintahan Islam di Madinah seperti layaknya kepala Negara. ${ }^{21}$ Dalam memutuskan suatu hukum dan metode kritik Hadits. ${ }^{22}$ Disamping itu, dalam buku ini al-Ghazali ingin menegaskan tentang kerjasama antara ahl al-Hadits dan ahl al-fiqh bahwa tugas ahl al-Hadits adalah mengumpulkan Hadits-Hadits, memperhatikan kualitas sanad dan matannya.Sedangkan tugas ahl al-fiqh adalah menyempurnakan tugas ahl al-Hadits denganmengetahui isi, matan dan relevansi Hadits dalam konteks syari'ah secara keseluruhan. ${ }^{23}$

Menurut Muhammad al-Ghazali ada lima kriteria ke shahihan Hadits, tiga terkait dengan sanad, dua terkait dengan matan. Tiga terkait dengan sanad, adalah:

a) Perawi memiliki tingkat kecerdasan dan kesadaran mengingat serta mampu menyalinnya sesuai dengan aslinya (dhâbith)

b) Perawi harus dikenal sebagai orang yang memiliki akhlak dan bertaqwa kepada Allah SWT serta menolak setiap penyimpangan yang terjadi pada periwayatan ( $\hat{a} \mathrm{dil}$ )

c) Kedua kriteria di atas harus ada dalam setiap rangkaian para perawi Hadits. Jika keduanya atau salah satu dari keduanyatidak memiliki oleh seorang perawi, maka Hadits itu akan gugur dari darajat Hadits shahih. ${ }^{24}$

Berbeda dengan mayoritas ulama' Hadits, Muhammad alGhazali tidak memasukkan unsur ketersambungan sanad sebagai kriteria keshahihan Hadits, bahkan unsur ketiga sebenarnya sudah masuk dalam kriteria kedua dan ketiga.Dalam hal ini, Muhammad

21 Moh. Wardi, "Interpretasi Kenabian (Peran Ganda Nabi Muhammad Sebagai Manusia Biasa dan Rasul)" Jurnal al-Ulum Jurnal Pemikiran dan Penelitian keislaman Universitas Islam Madura Vol. 2 No. 1 Juni 2015, 6.

22 Daniel W. Briwn, Menyoal Relevansi Sunnah dalam Islam, terj. Jaziar Radianti dan Entin Sriani Muslim, (Bandung: Mizan, 2000), 138.

23 Ibid, 19-21

${ }^{24}$ Ibid, 18-19 
al-Ghazali tidak memberikan argumintasi, sehingga sangat sulit untuk ditelusuri, apakah merupakan salah pemikiran atau unsur kesengajaan yang dilakukan olehnya.

Adapun dua kriteria yang terkait dengan matan, adalah

a) Matan Hadits tidak syadz (salah seorang atau beberapa rawinya bertentangan dengan periwayatannya dengan perawi yang lain yang lebih akurat dan lebih dipercaya)

b) Matan Hadits tidak mengandung 'illat qadîhah (cacat yang diketahui oleh pera ahli Hadits, sehingga mareka menolaknya). ${ }^{25}$ Dalam hal ini tidak ada kesempatan di kalangan ulama tentang langkah-langkah dalam studi matan. Apakah terhindar dari syadh kemudian terhindar dari 'illat atau sebaliknya.

Menurut Muhammad al-Ghazali, untuk memperaktekkan kriteria-kriteria tersebut, maka perlu kerjasama atau saling sapa antara muhaddits dengan berbagai ahli dibidangnya, termasuk fuqaha',mufassir, ahli ushul fiqih, ahli kalam dan lain-lain, mengingat materi Hadits ada yang berkenaan dengan aqidah, ibadah dan muamalah sehinga memerlukan pengetahuan dari berbagai ahli. ${ }^{26}$ Muhammad al-Ghazali menunjukkan beberapa contoh kekeliruan yang muncul akibat tidak adanya saling kompromi antaraahl al-Hadits dengan para pakar dibidang lainnya.

Muhammad al-Ghazali tidak memberikan penjelasan langkahlangkah kongkrit yang berupa tahapan-tahapan dalam memahami Hadits Nabi Saw. Namun dari berbagai pernyataannya dalam alSunnah al-Nabawiyyah Bain Ahl al-Fiqh waahl al-Hadits, dapat ditarik kesimpulan tentang tolok ukur yang dipakai Muhammad alGhazali dalam kritik matan (otentisitas matan dan pemahaman matan). Secara garis besar metode yang digunakan oleh Muhammad al-Ghazali ada 4 macam, yaitu:

\section{Pengujian Dengan al-Qur'an}

Muhamad al-Ghazali mengecam keras orang-orang yang memahami dan mengamalkan tekstual Hadits-Hadits yang shahih sanadnya, namun matan bertentangan dengan al-Qur'an. Pemikiran tersebut dilatar belakangi adanya keyakinan tentang kedudukan Hadits sebagai otoritas kedua setelah al-Qur'an, tidak semua Haditsorisinal, dan tidak semua Hadits dipahami secara benar oleh

25 Ibid, 19.

26 Ibid, 19-21 
periwayatnya. ${ }^{27}$ adalah sumber pertama dan utama dari pemikiran dan dakwah, sementara Hadits adalah sumber kedua. Dalam memahami al-Qur'an, kedudukan Hadits sangatlah penting, karna Hadits adalah penjelas teoritas dan peraktis bagi al-Qur'an. Oleh sebab itu, sebelum melakukan kajian terhadap matan Hadits, perlu upaya intensif memahami al-Qur'an, sebagai mana pernyataan Muhammad al-Ghazali:

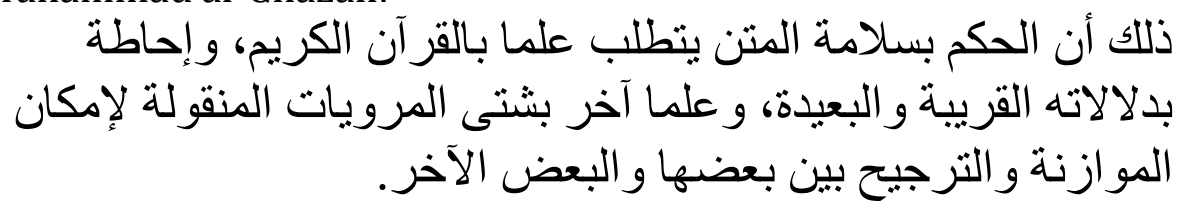

"Jelas bahwa untuk menetapkan kebenaran suatu hadits dari segi matannya diperlukan ilmu yang mendalam tentang al-Qur'an serta kesimpulan-kesimpulan yang dapat ditarik ayat-ayat-nya, baik secara langsung atau tidak..."28

Bagi Muhammad al-Ghazali, kebiasaan mengkaji al-Qur'an dengan porsi yang lebih sedikit dari Hadits tidak mungkin dapat memberikan gambaran yang tepat dan mendalam tentangIslam. Muhammad al-Ghazali menggunakan pengujian dengan alQur'an.Pengujian dengan al-Qur'an yang dimaksudkan adalah setiap Hadits harus dipahami dalam kerangka makna-makna yang ditunjukkan dalam al-Qur'an, atau pesan-pesan, semangat dan nilai-nilai yang dikandung dalam al-Qu'an, ataupun dengan menganaloqkan (qiyâs) yang didasarkan pada hukum-hukum alQua'an.

Pengujian dengan ayat-ayat al-Qur'an ini mendapat porsi perhatian terbesar dari Muhammad al-Ghazali dibanding tiga tolok ukur lainnya.Bahkan M.Quraish Shihab beranggapan bahwa, meski Muhammad al-Ghazali menawarkan empat tolok ukur, kaidah pertama-lah satu-satunya kaidah yang digunakan Muhammad alGhazali. ${ }^{29}$

Penerapan kritik Hadits dengan pengujian al-Qur'an dijalankan secara konsisten oleh Muhammad al-Ghazali. Oleh karena itu, tidak sedikit Hadits-Hadits yang dianggap shahih misalnya yang terdapat dalam kitab Shahih al-Bukhârî dan shahih

${ }^{27}$ Muhammad al-Ghazali, al-Sunnah al-Nabawiah baina Ahl al-Fiqh wa Ahl hadits. 18-21

28 Ibid. 19

${ }^{29}$ M. Quraish Shihab, "kata pengantar" dalam Muhammad al-Ghazali Studi Kritik atas Hadits Nabi SAW. Antara Pemahaman Tekstual dan Kontestual, terj.Muhammad al-Baqir (Bandung: Mizan, 1996), 11 
muslimdipandang dhâ'if oleh Muhammad al-Ghazali. Bahkan secara tegas dia mengatakan bahwa dalam hal-hal yang berkaitan dengan persoalan kemaslahatan dan mu'amalah dunyawiyyah, akan mengutamakan Hadits yang sanadnya dhâ'if, bila kandungan maknanya sinkron dengan inti ajaran al-Qur'an. Contoh hadits

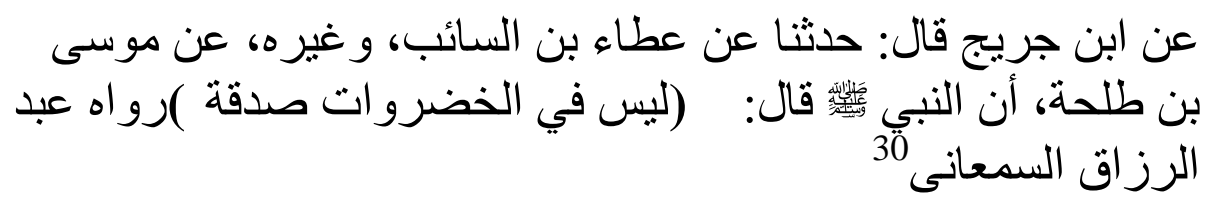

Dari Ibn Juraij, dia berkata aku menceritakan dari 'Atha' Ibn Sa'ib dan dari lainnya dari Musa Ibn Thalhah bahwa Nabi SAW bersabda " tidak ada shdaqah (zakat) di dalam sayur-sayuran ".

Hadits ini bertentangan dengan kandungan ayat al-Qur'an tentang diwajib kannya zakat atas hasil bumi tanpa terkejuali, seperti dalam QS: al-An'am (6):141

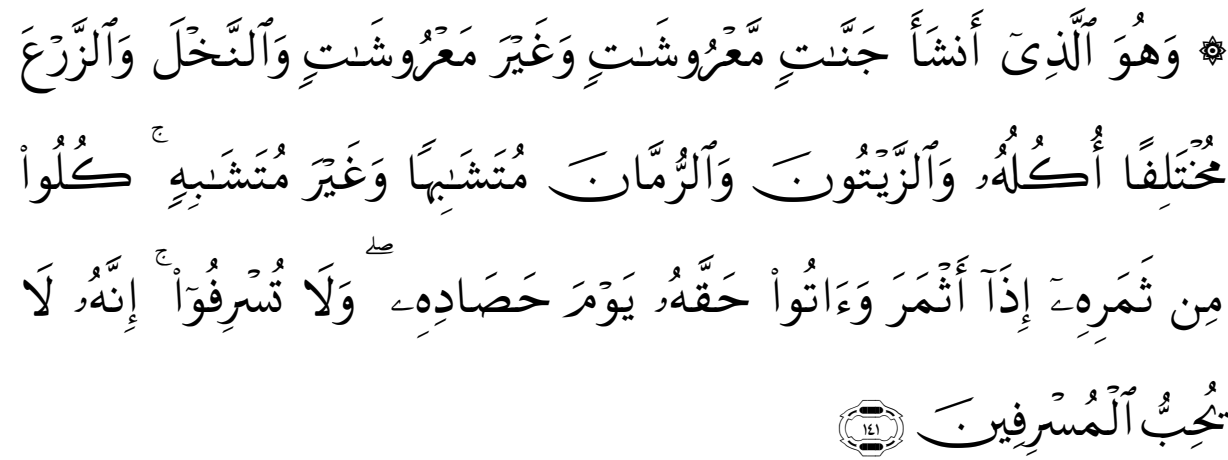

Artinya: Dan dialah yang menjadikan kebun-kebun yang berjunjung dan yang tidak berjunjung, pohon korma, tanam-tanaman yang bermacam-macam buahnya, zaitun dan delima yang serupa (bentuk dan warnanya) dan tidak sama (rasanya). makanlah dari buahnya (yang bermacam-macam itu) bila dia berbuah, dan tunaikanlah haknya di hari memetik hasilnya (dengan disedekahkan kepada fakir miskin); dan janganlah kamu berlebih-lebihan. Sesungguhnya Allah tidak menyukai orang yang berlebih-lebihan.

30 Abu Bakar Abd al-Razzaq Ibn Hammam Ibn Nafi' al-Humairi al-Yamani alShan'ani, Mushannaf Abd al-Razzaq al-San'ani, Jilid IV, (Beirut: Al-Maktab alIslami, t.t), 118 
Muhammad al-Ghazali tidak menerima pendapat yang mentidak wajibkan zakat atas sayuran karena cepat rusak sehingga tidak bisa disimpan di bait al-mâl.

Kemudian juga, Hadits yang menjelaskan tentang balasan Neraka bagi orang yang menguburkan bayi perempuan hiduphidup dan yang menguburnya.Yaitu :

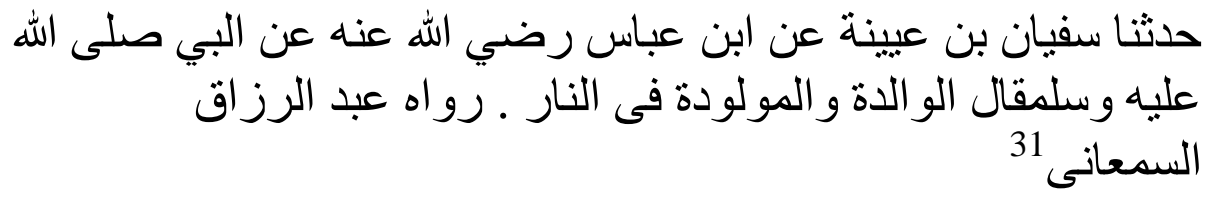

Menceritakan kepada kami Sufyan Ibn 'Uyainah dari Ibn Abbas ra dari Nabi SAW bersabda bahwa Ibu dan anak perempuan yang dikubur (hidup-hidup) di Neraka.

Menurut Muhammad al-Ghazali, Hadits tersebut bertentangan dengan al-QS; Al-Takwir (81) : 8-9 :

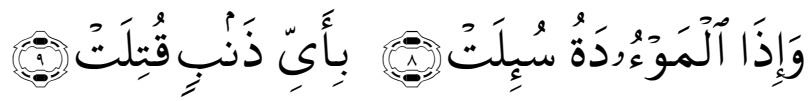

dan apabila bayi-bayi perempuan yang dikubur hidup-hidup ditanya, karena dosa Apakah Dia dibunuh,

\section{Pengujian Dengan Hadits}

Pengujian ini memiliki pengertian bahwa matan Hadits yang dijadikan dasar argumen tidak bertentangan dengan Hadits mutawatir dan Hadits lainnya yang lebih shahih.Menurut Muhammad al-Ghazali, suatu hukum yang berdasarkan pada agama tidak boleh diambil hanya dari Hadits yang terpisah dari yang lainnya.Tetapi, setiap yang harus dikaitkan dengan Hadits lainnya. Kemudian Hadits-Hadits yang terkabung itu dikomparasikan dengan apa yang ditunjukkan oleh al-Qur'an al-Karim. ${ }^{32}$

Adapun contoh dari hal tersebut adalah Hadits tentang hukum memakai sarung sampai di bawah mata kaki (memanjangkan kain sarung), seperti yang disabdakan di dalam haditsnya :

\footnotetext{
31 Ibid, Jilid V, 215

32 Muhammad al-Ghazali, al-Sunnah al-Nabawiah baina Ahl al-Fiqh wa Ahl hadits. 142.
} 


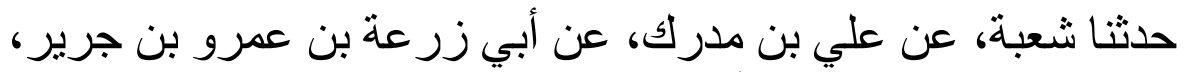

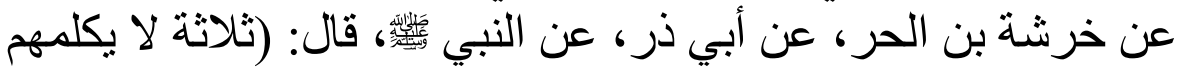

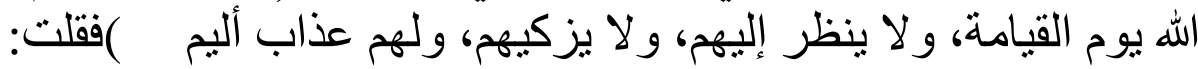

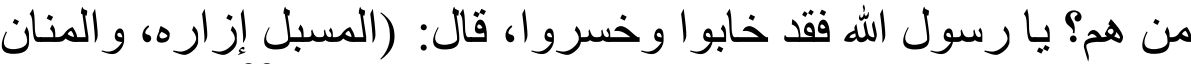
عطاءه، و المنفق سلعته بالحلف الكاذب) رو اله اهن ابن ماجه 33

“Menceritakan kepada kami Syu'bah dari Ali Ibn Mudrik dari Abi Zar'ah Ibn Amr Ibn Jarir dari Khirsyah Ibn Har dari Abu Dzar dari Nabi SAW beliau bersabda "tiga golongan orang yang tidak pernah diajak komunikasi oleh Allah di hari kiamat dan tidak dilihatnya, tidak disucikannya dan mereka mendapatkan siksa yang pedih, kemudian aku bertanya, siapa mereka wahai Rasulullah sungguh mereka kecewa dan rugi, beliau menjawab "orang yang mengendorkan sarungnya, orang yang menceritakan pemberiannya, dan orang yang menjual dagangannya dengan sumpah yang bohong".

Dan Hadits lain yang bersumber dari Abu Dzar yaitu :

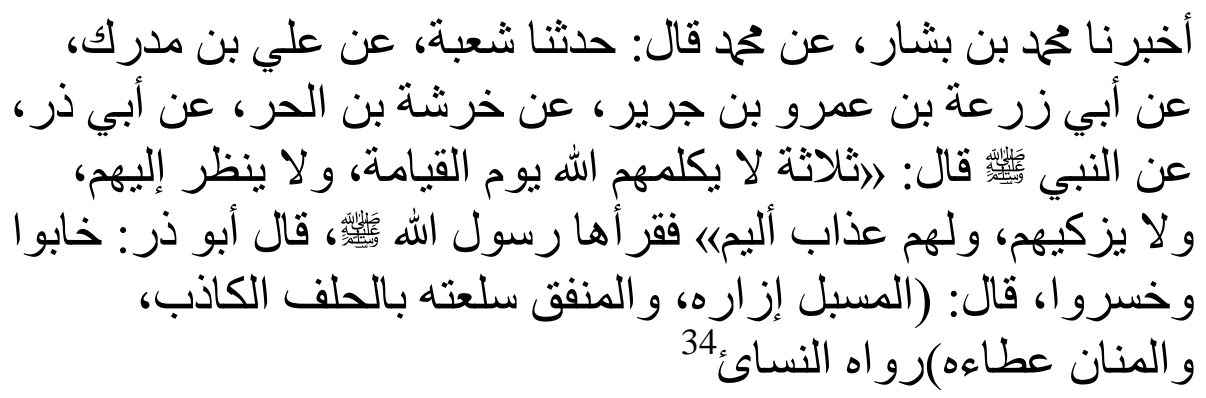

"Mengabarkan kepada kami Muhammad Ibn Basyyar dari Muhammad, dia berkata menceritakan kepada kami Syu'bah dari Ali Ibn Mudrik dari Abu Zar'ah Ibn Amr Ibn Jarir dari Khirsyah Ibn alHar dari Abu dzar dari Nabi SAW beliau bersabda "tiga yang tidak akan diajak bicara oleh Allah pada hari kiamat dan tidak dilihat, dan tidak disucikan, dan mereka mendapatkan siksa yang pedih, kemudian Nabi SAW membaca tiga itu, Abu Dzar berkata "mereka kecewa dan rugi, Nabi bersabda "orang yang memperpajang sarungnya, orang yang menjual barang dagangannya dengan sumpah yang bohong, dan orang yang menceritakan pemberiannya".

33 Abu Abdullah Muhammad Ibn Yazid al-Quzwini, Sunan Ibn Majah, Jilid II, (Beirut: Dar Ihya' al-Kutub al-'Arabiyah, t.t), 744

34 Abu Abdurrahman Muhammad Ibn Syu'ib Ibn Ali al-Khurasani al-Nasa'ie, Sunan al-Nasa'ie, Jilid VII, (kairo: Dar al-Kutub al-Islamiyah, t.t), 245 
Kemudian Hadits tersebut dipertegas dengan Hadits lain :

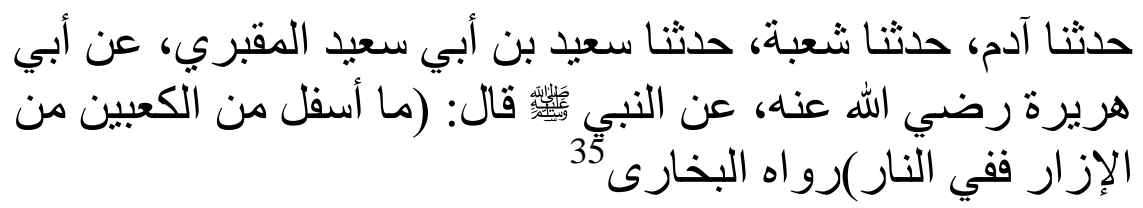

"Menceritakan kepada kami Adam, menceritakan kepada kami Syu'bah, menceritakan kepada kami Sa'id ibn Abi Sa'id al-Maqburi dari Abu Hurairah dari Nabi SAW "sesuatu yang lebih panjang dari kedua mata kaki dari sarung maka ia adalah di dalam neraka."

Hadits tersebut memberikan pemahaman bahwa orang yang berpakaian berjela-jela sampai di bawah mata kakinya, maka ia akan masuk Neraka sebagai hukuman atas perbuatannya. Kain yang dipakai di dalam Hadits tersebut menurut Muhammad alGhazali adalah kiasan terhadap tubuh orang yang memakainya.

Akan tetapi, orang yang membaca sejumlah Hadits yang membicarakan masalah ini akan mengetahui dengan jelas pendapat yang dianggap lebih kuat oleh Imam Nawawi dan Ibn Hajar dan lainnya bahwa kemutlakan Hadits tersebut dikaitkan dengan kesombongan yang dikena ancaman sebagaimana yang sepakati para ulama'. Hal ini dipertegas oleh hadits yang diriwayatkan oleh Imam Bukhari yaitu :

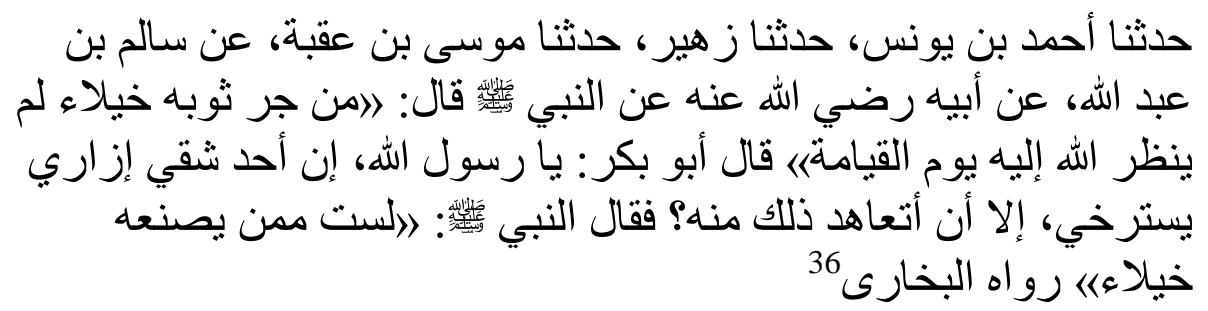

Menceritakan kepada kami Ahmad Ibn Yunus, menceritakan kepada kami Zuhir, menceritakan kepada kami Musa Ibn 'Uqbah dari Salim Ibn Abdullah dari bapaknya dari Nabi SAW belia bersabda "barang siapa yang menarik pakaiannya sampai melilit, maka Allah tidak akan memandangnya pada hari kiamat.Abu bakar bertanya "wahai Rasulullah sesungguhnya salah satu dua sisi sarungku terlalu melelet

\footnotetext{
35 Abu Abdullah Muhammad Ibn Isma'il al-Ju'fi al-Bukhari, Sahih al-Bukhari, Jilid VII, (Damaskus: Dar al-Kutub al-Islamiyah, t.t), 141

36 Ibid, Jilid VII, 141
} 
kecuali aku merubahnya?" beliau menjawab "engkau bukan termasuk dari orang yang berbuat melelet itu."

Menurut Ibn Abd al-Bar penghafal Hadits dan pakar fikih berkata bahwa maksud dari memanjangkan kain tanpa didasari dengan kesombongan tidak terkena ancaman tersebut, hanya saja dengan memanjangkan kain dan pakaian lainnya memang sangat tercela bagaimanapun keadaannya. ${ }^{37}$

Memanjangkan kain (sarung) yang mendapatkan ancaman dengan syarat adanya niat sombong tersebut diperkuat dengan konteks Hadits tersebut bahwa ancaman yang disebutkan di dalam Hadits adalah ancaman yang sangat keras sehingga orang yang memanjangkan kain termasuk salah satu golongan yang tidak akan diajak komunikasi dan bisa melihat Allah nanti di hari Kiamat. Allah tidak akan melihat dan menyucikannya, dan mereka akan mendapatkan siksa yang sangat pedih. Di dalam hadits itu Rasulullah SAW mengulang kata-kata yang berkaitan dengan ancaman tersebut sebanyak tiga kali.

Adapun yang menjadi perhatian agama Islam di sini adalah persoalan yang berkaitan dengan niat dan aspek batin yang berada di balik perbuatan lahir, yaitu sifat sombong, membanggakan diri, dan penyakit hati lainnya yang dapat menghalangi orang untuk masuk ke dalam surga.

Kemudian, maksud dari Hadits tersebut adalah berkaitan dengan bentuk pakaian yang sangat tergantung kepada adat dan kebiasaan dengan satu bangsa yang terkadang berlainan antara satu dengan lainnya, tergantung kepada adanya cuaca panas dan dingin, kaya dan miskin, mampu dan tidak mampu, jenis pekerjaan, taraf kehidupan, dan pengaruh-pengaruh lainnya. ${ }^{38}$

Di sini, syari'at memberikan keringanan kepada umat manusia di dalam menjalankan proses kehidupan dan mencegah hal-hal yang dianggap berlebihan secara lahir dengan tujuan membanggakan dan menyombongkan diri dan lainnya.

\section{Dengan Fakta Historis}

Suatuhal yang tidak bisa dipungkiri, bahwa Hadits muncul dalam historis tertentu, ${ }^{39}$ oleh karenanya antara Hadits dan sejarah memiliki hubungan sinergis yang saling menguatkan satu samalain.

\footnotetext{
37 Yusuf al-Qaradhawi, Metode Memahami Sunnah Dengan Benar, Terj. Syaifullah Kamali, 182

38 Ibid, 185

${ }^{39}$ Ibid, 205
} 
Adanya kecocokan antara Hadits dengan fakta sejarah akan menjadikan Hadits memiliki sandaran validitas yang kokoh, demikan pula sebaliknya bila terjadi penyimpangan antara dengan sejarah, maka salah satu diantara keduanya diragukan kebenarannya. Contoh Hadits

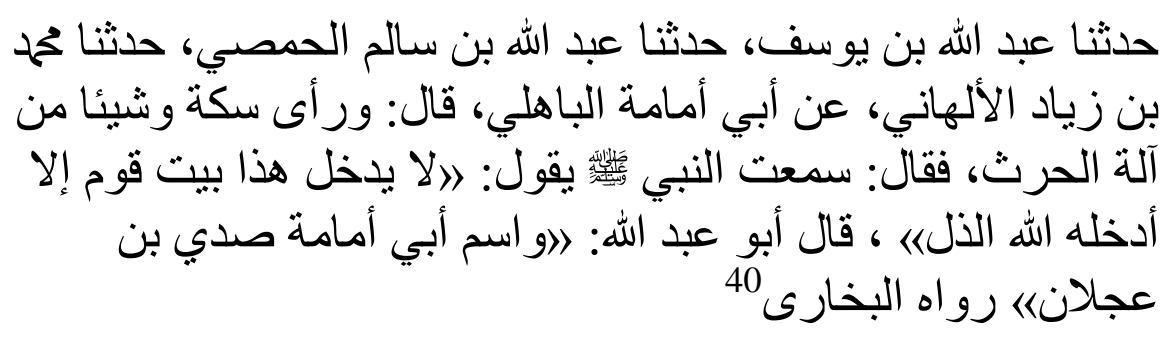

Menceritakan kepada kami Abdullah Ibn Yusuf, menceritakan kepada kami Abdullah Ibn Salim al-Himshi, menceritakan kepada kami Muhammad Ibn Ziyad al-Alhani dari Umamah al-bahily, dia berkata "dia melihat cangkul dan alat bercocok tanam".Dia berkata "aku mendengar dari Nabi SAW bersabda "bahwa tidak akan masuk alat ini ke rumah suatu kaum, kecuali Allah pasti memasukkan kehinaan ke dalamnya."

Menurutnya, Hadits tersbut bertentangan dengan fakta historis, di mana orang-orang Anshar mempunyai pekerjaan di bidang pertanian dan perkebunan.Di samping itu, Rasulullah SAW tidak pernah memerintahkan mereka untuk meninggalkan pekerjaan itu, yang itu juga bertentang dengan Hadits Nabi SAW sebagai berikut:

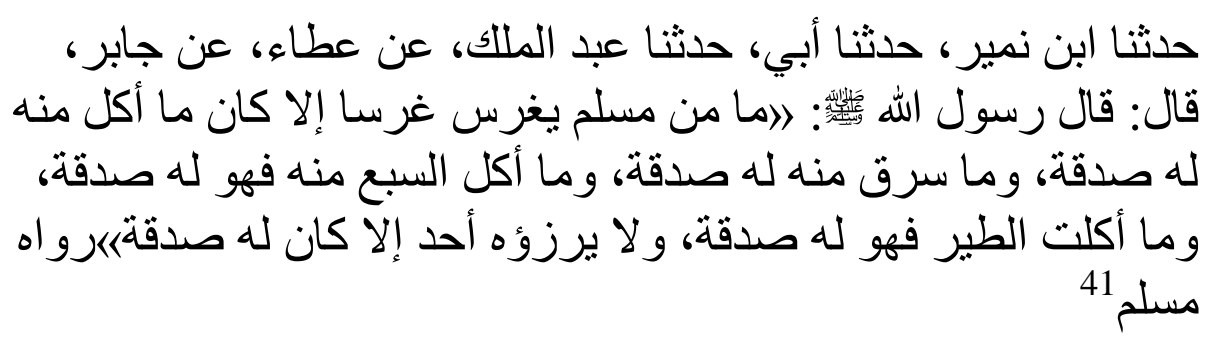

Menceritakan kepada kami Ibn Numair, menceritakan kepada kami Ubai, menceritakan kepada kami Abdul Malik, dari Atha' dari Jabir

\footnotetext{
${ }^{40} \mathrm{Abu}$ Abdullah Muhammad Ibn Isma'il al-Ju'fi al-Bukhari, Sahih al-Bukhari, Jilid III, 103

41 Muslim Ibn Hajjaj Abu al-Hasan al-Qusyairi al-Naisaburi, Sahih Muslim, Jilid III, (Beirut: Dar Ihya' al-Turath al'Arabi, t.t), 1188
} 
dia berkata bahwa Rasulullah SAW bersabda "tiadalah dari seorang muslim yang menanam tanaman kecuali apa yang dimakan darinya termasuk dari shadaqah, apa yang dicuri darinya adalah shadaqah, dan apa yang dimakan oleh binatang buas adalah shadaqah, dan apa yang dimakan burung kecuali shadaqah, dan apa yang dipetik oleh seseorang kecuali menjadi shadaqah".

Kemudian bertentangan dengan Hadits :

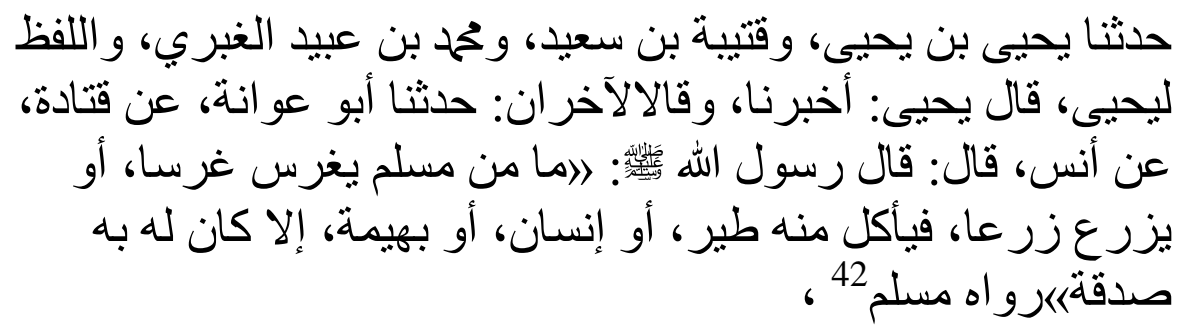

Menceritakan kepada kami Yahya Ibn Yahya, dan Qutaibah Ibn Sa'id dan Muhammad Ibn 'Ubaid al-Ghubari, sedangkan lafadz hadits milik Yahya, dia berkata, menceritakan kepada kami dan perawi yang lain berkata menceritakan kepada kami Abu 'Awanah dari Qatadah dari Anas dia berkata " bahwa Rasulullah SAW bersabda" tiadalah dari seorang muslim yang menanam tanaman atau bercocok tanam, kemudian dimakan sebagian oleh burung, manusia, binatang kecuali ia menjadi shadaqah.

Kemudian Hadits :

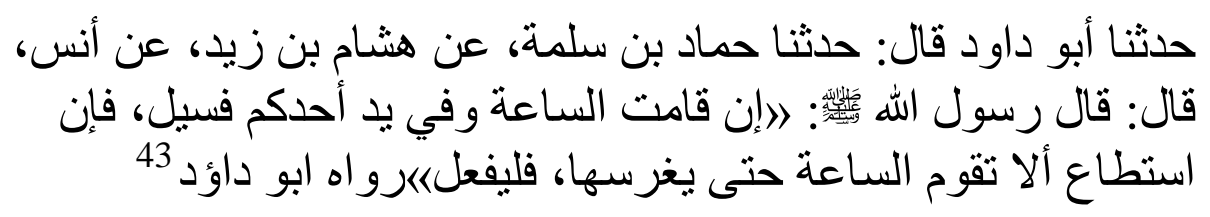

Menceritakan kepada kami Abu Daud, dia berkata : menceritakan kepada kami Hammad Ibn Salamah dari Hisyam Ibn Zaid dari Anas, dia berkata bahwa Rasulullah SAW bersabda "jika kiamat tiba dan di tangan kamu sekalian alat bercocok tanam, maka tidak akan terjadi kiamat sehingga engkau menanamnya, maka hendaknya ia menanam".

\footnotetext{
42 Ibid, 1189

43 Abu Daud Sulaiman Ibn Daud Ibn Jarud al-Thayalisi, Musnad Abi Daud alThayalisi, Jilid III, (Mesir: Dar Hijr, t.t), 545
} 
Dari Hadits yang menjelaskan tentang keutamaan bercocok tanam menunjukkan bahwa para petanni mendapatkan pahala atas hasil tanamannya yang diambil oleh siapapun, meskipun ia sendiri tidak meniatkannya untuk shadaqah.

Setelah mengemukakan beberapa conoth Hadits yang setema tersebut di atas, dengan mengutip pendapat Ibn Hajar, Muhammad al-Ghazali berkesimpulan bahwa celaan terhadap pertaniaan berlaku bila orang tersebut dengan bercocok tanam dapat melalaikan agama, seperti jihad dan lain sebagainya. Sebaliknya, jika pertanian tersebut mendukung terhadap kelangsungan kehidupan serta tidak melalaikan kewajiban agama serta tidak melampaui batas dalam penggunaan, maka pertanian tersebut sangat dianjurkan dan mendapatkan pahala dari Allah. ${ }^{44}$ Di samping itu, Hadits-Hadits tentang pertanian di atas mengisyaratkan bahwa setiap muslim selalu dituntut agar berkarya dan berjasa, di antaranya dengan bercocok tanam. Kemudian juga, Hadits tersebut menganjurkan penghijauan. ${ }^{45}$

Muhammad al-Ghazali di dalam memahami Hadits dengan metode tematis ini masih terkesan hanya mengkompromikan Hadits-Hadits yang secara lahir bertentangan. Memahami Hadits dengan menggunakan metode tematik harus diakui masih merupakan suatu kajian yang sangat eksklusif dan kurang membumi di kalangan pengkaji Hadits dibandingkan dengan kajian tematik terhadap al-Qur'an. ${ }^{46}$

\section{Pengujian Dengan Kebenaran Ilmiah}

Pengujian ini bisa diartikan bahwa setiap kandungan Hadits tidak boleh bertentangan dengan teori ilmu pengetahuan atau penemuan ilmiah; dan juga memenuhi rasa keadilan antar tidak bertentangan dengan hah asasi manusia. Oleh sebab itu adalah tidak masuk akal bila ada Hadits Nabi mengabaikan rasa keadilan, dan menurutnya, bagaimana shahihnya sanad sebuah Hadits, jika muatan informasinya bertentangan dengan prinsip-prinsip keadilan dan prinsi-prinsip hak asasi manusia maka Hadits tersebut tidak layak pakai.Jika dicermati indikator yang ditawarkan oleh Muhammad al-Ghazali dalam keritik matan bukanlah sesuatu

\footnotetext{
${ }^{44}$ Yusuf al-Qaradhawi, Kaif Nata'mal Ma'a al-Sunnah, 110-111

45 Yusuf al-Qaradhawi, Min Ajl al-Shahwah al-Rasyidah, (Mesir: Dar al-Wafa, 1995), 16. Kemudian juga di dalam kitabnya Yusuf al-Qaradhawi, Al-Sunnah Mashdaran li al-Ma'rifah wa al-Hadharah, (kairo: Dar al-Shuruq, 1997), 144

46 Komaruddin Hidayat, Memahami Bahasa Agama; Sebuah Kajian Tematik, (Jakarta: Paramadina, 1996), 193
} 
yang baru Muhammad al-Ghazali sendiri mengakui bahwa apa yang dilakukannya sudah dilakukan oleh ulama-ulama terdahulu yang paling penting dari semua itu adalah bagai mana memperaktikkan indikator matan tersebut dalam berbagai matan Hadits nabi.

Menurut penulis, sebelum mengkaji lebih jauh tentang kriteria studi matan yang ditawarkan oleh Muhammad al-Ghazali, satu hal dicatat, keempat pengujian tersebut tidak serta merta dapat diterapkan secarapenuh untuk semua matanHadits. Dari 48 contoh Hadits yang diangkatoleh Muhammad al-Ghazali dapat dikategorisasikan menjadi lima yakni:(1) pengujian dengan alQur'an, Hadits, fakta historis dan kebenaran ilmiah (2) pengujian dengan al-Qur'an, fakta historis dan kebenaran ilmiah (3) pengujian dengan Hadits, fakta historis dam kebenaran ilmiah (4)pengujian dengan fakta historis dan kebenaran ilmiah (5) pengujian dengan ilmiah. Contoh Hadits.

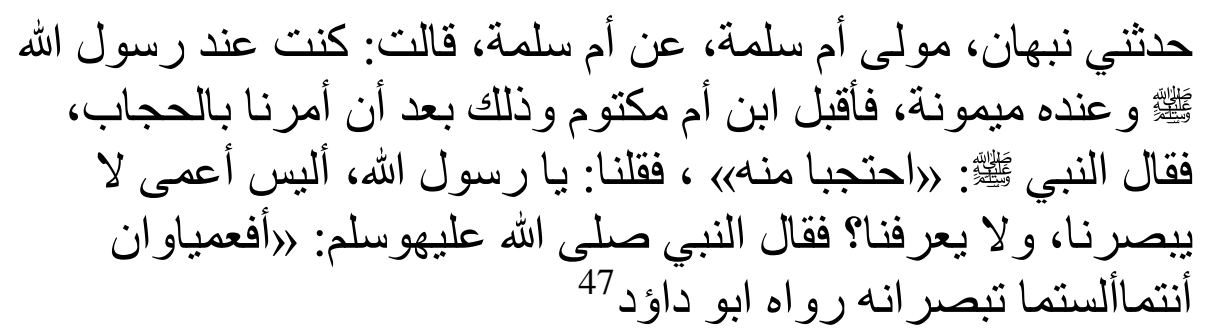

Menceritakan kepada kami Nabhan buda' ummu Salamah dari Ummu Salamah dia berkata "aku ada di sisi Rasullah SAW dan di sisinya juga terdapat Maimunah, kemudian Ummi Maktum menghadap beliau setelah menyuruh kami untuk memakai tutup (jilbab), kemudian Nabi SAW bersabda "memakai tutuplah kamu berdua darinya".Kami menjawab "wahai Rasulullah bukankah dia buta tidak bisa melihat kami dan tidak mengenali kami, Nabi SAW bersabda "apakah kamu berdua buta, bukankah kamu sekalian bisa melihat?".

Hadits ini menurut Imam al-Tirmidzi bernilai hasan shahih, sedangkan menurut Muhammad al-Ghazali lemah, karena di dalamnya terdapat Nabhan Maula Ummi Salamah yang majhûl (tidak dikenal pribadinya). Hadits ini bertentangan dengan Hadits yang diriwayatkan oleh Imam Bukhari dan Muslim, yaitu :

\footnotetext{
${ }^{47}$ Abu Daud Sulaiman Ibn Asy'asth Ibn Ishaq Ibn Basyir Ibn Syaddad ibn Amr alZadi, Sunan Abu Daud, Jilid IV, (Beirut: Dar al-Makatabah al-'Ashriyah, t.t),63
} 


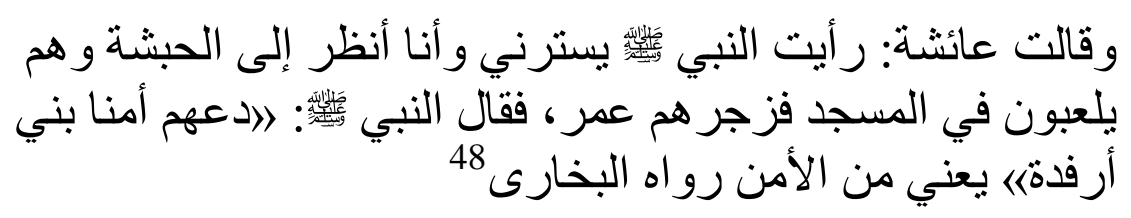

Dan berkata Aisyah bahwa aku melihat Nabi SAWmenutupiku sedangkan saya melihat Habshah bermain-main di masjid kemudian dilaranglah mereka oleh Umar, Nabi bersabda "biarkan mereka dalam keadaan aman wahai Bani Arfadah."

Hadits ini menjelaskan kebolehan bagi wanita memandang laki-laki yang bukan mahram.Muhammad al-Ghazali mengkompromikan Hadits di atas dengan menukil pernyataan Imam al-Qurtubi yang menyatakan bahwa Hadits yang menyatakan tentang larangan wanita melihat laki-laki itu menunjukkan kenyataan betapa Nabi SAWlebih memperberat atas istri-istri beliau demi menjaga kehormatan diri mereka, sebagaimana beliau memperberat atas mereka tentang urusan hijab. ${ }^{49}$ Sedangkan secara umum dapat disimpulkan bahwa perempuan boleh melihat bagian tubuh laki-laki, sama seperti halnya perempuan boleh melihat laki-laki selama tida diiringi dengan syahwat.

Kemudian Hadits yang kesannya kontradiktif adalah Hadits tentang ziarah kubur bagi wanita. Seperti yang dijelaskan oleh Nabi SAW:

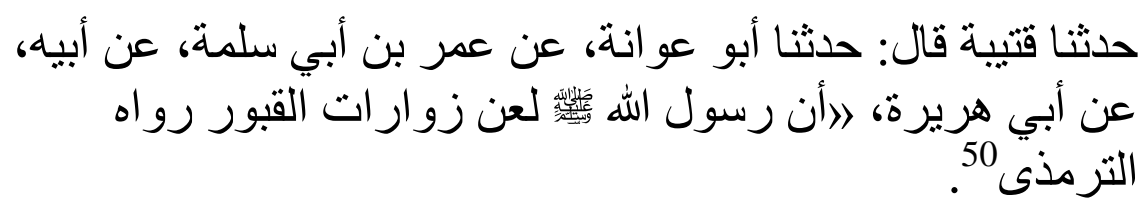

Menceritakan kepada kami Qutaibah dia berkata menceritakan kepada kami Abu 'Awanah dari Umar Ibn Abi Salamah dari bapaknya dari Abu Hurairah bahwa Rasulullah SAW melaknat orang prempuan yang berziarah kubur.

Hadits ini dinilai shahih dan mengandung pengertian tentang ketidak sukaan Nabi SAWkepada perempuan yang terlalu sering

${ }^{48} \mathrm{Abu}$ Abdullah Muhammad Ibn Isma'il al-Ju'fi al-Bukhari, Sahih al-Bukhari, Jilid II, 23

${ }^{49}$ Yusuf al-Qaradhawi, Kaif Nata'mal Ma'a al-Sunnah , 114

50 Muhammad Ibn 'Isa Ibn Thaurah Ibn Musa Ibn Dhahhak al-Turmudzi, Sunan al-Turmudzi, Jilid III, (Mesir: Muktabah Musthafa al-Halbah, t.t), 362 
berziarah kubur. Hadits ini bertentangan dengan Hadits yang memprobolehkan ziarah kubur secara umum, seperti yang disabdakan oleh Nabi SAW :

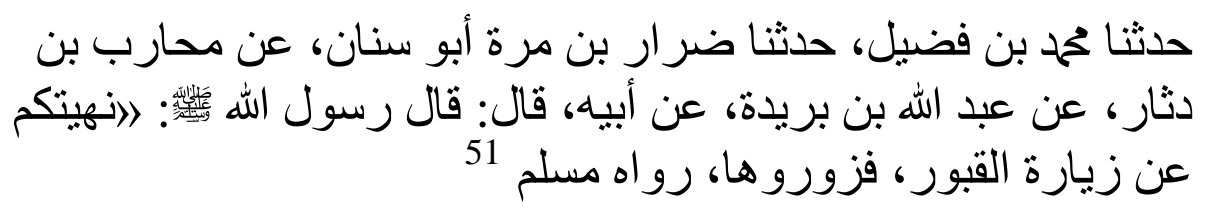

Menceritakan kepada kami Muhammad Ibn Fudhail, menceritakan kepada kami Dharrar Ibn Murrah Abu Sinan dari Maharib Ibn Datthar dari Abdullah Ibn Baridah dari bapaknya dia berkata bahwa Rasulullah SAW bersabda "aku melarang kamu sekalian dari berziarah kubur, maka berziarahlah."

Hadits ini juga bernilai shahih. Dan juga adanya Hadits Nabi yng diriwayatkan oleh Imam Bukhari dan Muslin di dalam bab alJanaiz, yaitu :

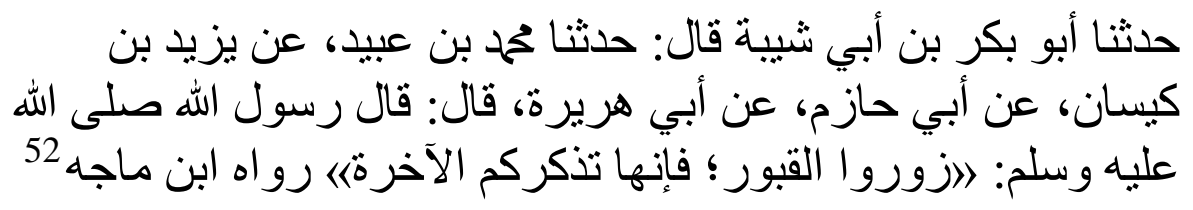

Menceritakan kepada kami Abu Bakar Ibn Abi Syaibah dia berkata 'menceritakan kepada kami Muhammad Ibn Ubaid dari Yazid Ibn Kaisan dari Abu Hazim dari Abu Hurairah dia berkata bahwa Rasulullah SAW bersabda "berziarahlah ke kuburan-kuburan karena ia akan mengingatkan kamu sekalian kepada akhirat."

Menurut Muhammad al-Ghazali menukil pendapatnya alQurtubi bahwa Hadits yang melarang ziarah kubur dapat dikompromikan, sebab, Hadits yang melarang perempuan ziarah kubur adalah dikarenakan wanita tersebut terlalu sering berziarah kubur yang akan menyebabkan terabaikannya kewajiban yang lain, sehingga dilarang oleh Nabi SAW. ${ }^{53}$

\footnotetext{
${ }^{51}$ Muslim Ibn Hajjaj Abu al-Hasan al-Qusyairi al-Naisaburi, Sahih Muslim, Jilid III,1563

52 Ibnu Majah Abu Abdullah Muhammad Ibn Yazid al-Quzwini, Sunan Ibn Majah, Jilid I, (Beirut: Dar Ihya' al-Kutub al-'Arabiyah, t.t), 500

53 Ibid, 117
} 


\section{Kontribusi Muhammadal-Ghzali Dalam Kajian Hadits Kontemporer}

Memahami Hadits Nabi SAW merupakan salah satu hal penting di dalam mendalami tentang ajaran agama Islam. Karena Hadits merupakan sumber ajaran Islam yang kedua setelah alQur'an yang memiliki fungsi tersendiri terhadap alQur'an.Memahami Hadits merupakan kunci memahami alQur'an.Sementara memahami al-Qur'an merupakan kebutuhan primer bagi umat Islam yang ingin mengetahui ajaran-ajaran agama Islam, sebab, Islam merupakan agama yang diturunkan oleh Allah melalui al-Qur'an.Keberislaman seseorang tidak bisa dikatakan kokoh tanpa di dasari pengetahuannya terhadap isi dan kandungan dari al-Qur'an. Sementara Hadits sebagai bagian dari alQur'an yang berfungsi untuk memperjelas makna-makna al-Qur'an yang masih global, sehingga memahami Hadits menjadi penting adanya.

Memahami Hadits tidak cukup dengan mengetahui arti perkata dari Hadits tersebut, tetapi harus didukung dengan seperangkat metodologis yang cukup sesuai dengan yang dijelaskan di atas.Dengan demikian, kesimpulan dari pemahaman yang diperoleh sangat ditentukan oleh metode yang dipakainya di dalam memahami Hadits tersebut. Sehingga setiap metode yang dipakai akan memiliki implikasi terhadap suatu pemahaman.

Adapun kontribusi yang telah dipaparkan oleh Muhammad al-Ghazali dalam dunia keilmuan Islam, dengan menggunakan metode tersebut di atas adalah sebagai berikut:

1. Terbebasnya dari kesalahan dan kekeliruan

Memahami Hadits dengan menggunakan metode yang telah dijelaskan di atas akan menjadikan peneliti terbebas dari kesalahan. Karena, metode merupakan salah satunya barometer atau pisau analisadi dalam memahami setiap informasi yang datang terkait dengan persoalan Hadits, karena Hadits merupakan ajaran Nabi SAWyang tidak lepas dari sosio-historis dan sosiokultural.Maka, memahami Hadits tidak bisa hanya dengan menggunakan pemahaman terhadap makna lafadz saja yang terdapat di dalam Hadits tanpa mengetahui lebih lanjut tentang latar belakang timbulnya (asbab al-wurud), kodisi sosio-kulturnya. Seperti pemahaman tentang hadits di bawah ini :' 


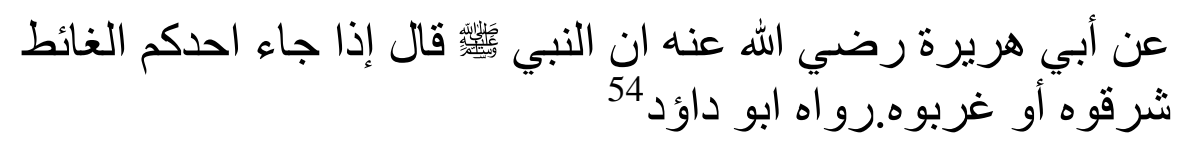

Dari Abu Hurairah R.A. Rasulullah bersabda: apabila salah satu di antara kalian mau berberak, maka hendaklah menghadap ke timur dan ke barat.

Hadits ini secara lafadz sangat relevan ketika digunakan untuk daerah tertentu yang ada di sebelah utara atau selatan Makkah, karena Hadits ini menjelaskan larang menghadap Ka'bah ketika menunaikan hajat, sehingga ketika pemahamannya hanya mengandalkan pemahaman lafadziyah saja, akan menjadi tidak relevan ketika Hadits ini dijadikan hujjah di daerah-daerah bagian timur dan barat dari Makkah dan Ka'bah.

2. Terbebas dari Keraguan

Memahami Hadits sebagai sumber ajaran Islam ke dua setelah al-Qur'an menjadi bagian penting di dalam ajaran Islam. Karena ia menjadi hujjah atau dasar dari setiap prilaku-prilaku ubudiyah maupun muamalah umat Islam di dalam menjalankan perintah agama Islam. Maka, pemahaman terhadap Hadits yang hanya mengandalkan lafadz dan makna tanpa di dasari dengan metode yang cukup dan benar, ia akan mengalami keraguan akan otentisitas Hadits tersebut. Karena Hadits sebagai sumber ajaran Islam yang datang setelah al-Qur'an. Sementara Hadits setelah perkembangannya tidak bisa dilepaskan dari proyek politik, ekonomi, dan lain sebagainya yang seringkali menjadikannya sebagai legitimasi dari kepentingan mereka, sehingga setiap Hadits nabi SAWyang tidak diketahui status dan otentisitasnya akan menjadikan pemerhati dan pengkajinya menjadi ragu di dalam menggunakannya sebagai hujjah di dalam beragama. ${ }^{55}$

Dengan demikian, memahami Hadits tidak bisa dilepaskan dari metode yang dipakai, sehingga seorang yang mencoba memahaminya dengan perangkat metode yang cukup, maka ia akan terbebas dari kesalahan dan keraguan akan status Hadits yang dikajinya untuk dijadikan hujjah di dalam hidupnya.

3. Mampu Membedakan antara Hadits atau Bukan

\footnotetext{
${ }^{54}$ Abu Daud Sulaiman Ibn Asy'asth Ibn Ishaq Ibn Basyir Ibn Syaddad ibn Amr alZadi, Sunan Abu Daud, Jilid I, 312

55 M. Syuhudi Ismail, Metodologi Penelitian Hadits, 15
} 
Seringkali ditemukan tentang ungkapan-ungkapan Arab yang hampir tidak bisa dibedakan antara Hadits atau hanya ungkapan Arab, sehingga muncul pengkaburan dan pencampur adukan antara Hadits dengan ungkapan-ungkapan tersebut.

Dengan demikian, perangkat metodologis merupakan hal penting di dalam memahami Hadits.Baik metode di dalam mengkai Hadits secara sanad (susunan perawi) atau pemahaman secara matan (redaksi Hadits).Sebab, Hadits merupakan sabda Nabi SAWyang sumbernya adalah wahyu dari Allah selain alQur'an.Iamenjadi suci adanya walaupun tidak dinamakan al-Qur'an kedua, sehingga orang yang belajar memahaminya tidak boleh tidak, harus menggunakan metode yang benar sehingga akan bisa membedakan mana yang Hadits mana yang bukan.

Pemahaman Hadits dengan menggunakan metode yang benar akan menghasilkan kesimpulan yang benar dan tidak menyalahi alQur'an, karena hadits merupakan penjelas dari al-Qur'an, sehingga keberadaannya menjadi sangat penting dan memahaminya juga menjadi perbuatan yang utama dan penting.

\section{Kritik Atas Kelemahan Pemikiran Muhammad al-Ghazali akan Metode Memahami Hadits.}

Ahl al-Hadits telah muncul sejak generasi sehabat, ${ }^{56}$ dengan berbagai persoalan kehidupan yang belum bagitu kompleks. Kelompok ini berpegang kepada arti lahiriah nash, karena dengan pandangan mareka kebenaran al-Qur'an bersifat mutlak, sedangkan kebenaran rasio adalah nisbi. Suatu yang nisbi tidak akan bisa menjelaskan suatu yang muthlaq ${ }^{57}$ keengganan mareka menggunakan akal ini, yang memjadikan mareka dijuluki ahl alhasyw (orang yang berpikir gampam-gampangan, lantaran mareka tidak mau mengunakan interpretasi rasional). Dengan demikian,

56 Di antara shahabat yang termasuk kelompok tekstualis adalah Bilal, `Abd alRahman bin `Auf, dan al-Zubair bin `Awwam. Sebagai satu contoh kasus, pembagian rampasan perang pada masa Khalifah `Umar bin al-Khattab yang tidak sesusai dengan Q.S.al-Anfal [8]: 4 dan yang diperaktekkan Nabi pada perang Khaibar ditentang keras oleh shahabat Bilal, 'Abd Rahman bin 'Auf, dan al-Zubair bin Awwam. Namun, kebijakan Umar tersesebut didukung oleh Utsman bin Affan, 'Ali bin Abi Thalib, Thalhah, `Abd Allah bin 'Umar (kelompok shahabat kontekstual). Lihat: Munawwir Sjadzali (dkk) Polemik Reaktualisasi Ajaran Islam ( Jakarta: Pustaka Panjimas, 1998), 10-27.

57 Hal ini bisa dilihat pernyataan 'Ahmad bin Hambal bahwa " kami tidak menakwilkan al-Qur'an dan tidak menakwilkannya dengan akal, sehebat akal terbatas". Lihat Ali Samil al-Nasyasyar, Nas'at al-Fikr al-Falsafi al-Islam (Kairo: Dar-al-Ma`arif, 1981), jilid I, 249. 
Hadits-Hadits âhâd memperoleh kedudukan yang lebih penting di kalangan kelompok ini.

Dalam memahami Hadits Nabi, secara garis besar dapat dibagi menjadi dua kelompok, yakni: (1) kelompok yang lebih mementingkan makna lahiriah teks Hadits disebut dengan ahl alHadits, tekstualis (2) kelompok yang mengembangkan penalaran terhadap faktor-faktor yang berbeda di belakang teks disebut ahl $a l-r a ' y$, kontekstual.

Munculnya kritik tajam yang ditujukan pada Muhammad alGhazali tersebut, disebabkan dua hal:

1. Muhammad al-Ghazali tidak mau mempergunakan Hadits âhâd dalam menetapkan akidah. Menurut Muhammad al-Ghazali, masalah akidah harus berdasarkan keyakinan, bukan dugaan ${ }^{58}$. Pendapat ini bersumber dariahl al-bid'ah, dan mereka berpecah menjadi dua:

a) Mu'tazilah, yang mengatakan bahwa HaditsAhad sifatnya hanya dhanni saja, dan sesuatu yang dhanni tidak layak untuk diamalkan, makanya kelompok ini menolak hadits ahad baik dalam masalah aqidah maupun hukum syar'i.

a) Ahl as-Asya'irah, mereka berpendapat bahwa Hadits ahad bersifat dhanni, sehingga hanya layak dijadikan hujjah pada masalah hukum saja dan tiak bias dijadikan hujjah dalam masalah aqidah.Fakta menetapkan bahwa kebenaran suatu berita tidak dilihat dari banyaknya pemberi kabar, namun dari sisi kualitas sang pembawa berita.

Perlu kita kaji makna kalimat dhanni (dugaan) tersebut, karena kalimat dhan yang banyak digunakan ulama fiqh adalah $a d-$ Dhan ar-Rajih (dugaan yang kuat) yaitu lawan kata dari istilah alWahm (dugaan yang lemah), dan ad-Dhan menurut para ulama fiqh adalah sesuatu yang bisa dijadikan landasan hukum, dan bukan bermakna dugaan ataupun prasangka yang diharamkan oleh agama, sebagaimana sabda Nabi:

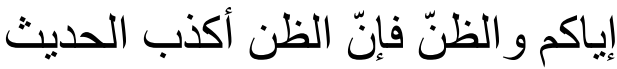

Jauhilah prasangka, karena prasangka adalah perkataan yang paling dusta.

58 Menurut Yusuf al-Qardhawi, jumlah hadits yang ditolak oleh Muhammad alGhazali sedikit dan penolakan tersebut bukan karena hawa nafsu, lemah dalam beragama, atau untuk menolak sunnah dan mengulangi nilai wahyu. Namun, dalam rangka membela agama dari serangan kaun sekuler dan ateis yang menjelek-jelekkan Islam, supaya ajaran Islam menjadi lemah. Lihat: Yusuf Qardhawi, al-Syaikh Muhammad al-Ghazali, 124-127. 
Dan mungkin perlu kami jelaskan pula bahwa diantara makna kalimat al-Dhann juga adalah alyakin, sebagaimana firman Allah:

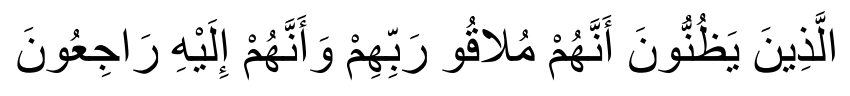

Artinya: yaitu orang yang yakin bahwa mereka akan berjumpa dengan Rabbnya dan mereka akan kembali kepadanya ${ }^{59}$.

Pijakan terkuat dari pendapat ini adalah akal, dan dalil-dalil syar'i menyelisihinya.Imran bin Husain, mematahkan syubhat lemah dari seseorang yang terkungkung nafsu, sekaligus mengukuhkan sebuah paradigma bahwa al-Qur-an dan sunnah bak dua mata uang yang tidak bisa dipisahkan. Dan dengarkan pula perkataan dari seorang ulama rabbani Ayub as-Sakhtiyanirahimahullah—agar kemudian kita menjauhi pemikiran sesat ini:

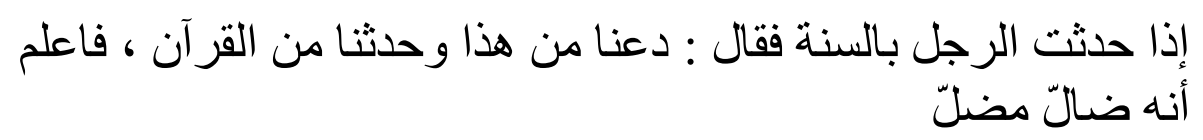

Jika engkau mengabari seseorang dengan hadits, kemudian dia mengatakan: jauhkanlah kami dari hadits dan bicaralah engkau dari al-Qur-an saja!!, ketahuilah bahwa orang tersebut sesat dan menyesatkan. ${ }^{60}$

Seandainya mereka -para ingkarus sunnah-menyadari bahwa pengingkaran terhadap sunnah Nabi SAW pada hakikatnya adalah perpanjangan dari pengingkaran terhadap al-Qur'an, pasalnya kitab suci tersebut sarat dengan perintah untuk mencintai, mengagungkan dan memuliakan serta mengikuti sunnah Nabi Muhammad SAW, beberapa contoh dari ayat tersebut:

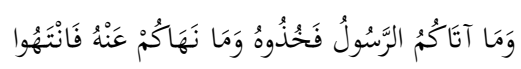

Artinya: Dan apa yang diperintahkan Rasul kepada kalian maka terimalah, dan apa yang dilarang oleh beliau maka tinggalkanlah. ${ }^{61}$

$$
\text { من يطع الرسول فقد أطاع الله }
$$

\footnotetext{
59 al-Baqarah 46

${ }^{60}$ Khathib al-Baghdadi, al-Kifayah Fi Ilmir Riwayah, juz,1, 29

61 al-Hasyr 7
} 
Artinya: Barangsiapa yang mentaati Rasul itu, maka sesungguhnya dia telah mentaati Allah. ${ }^{62}$.

$$
\text { ياأيها الذين آمنوا أطيعوا الله وأطيعوا الرسول وأولي الأمر منكم }
$$

Artinya: Wahai orang-orang yang beriman, taatilah Allah dan taatilah Rasulullah dan taatilah para pemimpin kalian ${ }^{63}$.

Oleh karena itu, tidaklah mengheran jika al-Imam Syafi'irahimahullah-menukil ijma' umat untuk mengagungkan sunnah Nabi kita yang tercinta, beliau mengatakan:

$$
\text { أجمع المسلمون على أن من استبانت له سنة رسول الله لم يكن له أن يدعه لقول أحد من الناس }
$$

Telah tegak ijma' kaum muslimin bahwa barang siapa yang telah jelas baginya sunnah Nabi, maka tidak boleh baginya untuk meninggalkan sunnah tersebut karena perkataan salah seorang manusia (ulama) ${ }^{64}$.

2. Penelitian Hadits pada kritik matan. kajian Muhammad alGhazali terhadap Hadits Nabi menitikberatkan pada kritik matan, dalam arti mengkaji otentisitas sebuah matan Hadits dan mengungkap makna (memahami Hadits Nabi). Hal inilah yang muncul sisi kelemahan Muhammad al-Ghazali, yakni dalam memaparkan pemikirannya kurangmemberikan perhatian yang cukup mendalam tentang masalah sanad ${ }^{65}$.Menurut ja'far Umar Thalib Muhammad al-Ghazali masuk dalam kategori kelompok al- Aqlaniyun dan buku Muhammad al-Ghazali anti sunnah alNabawiyyah dan merongrongsunnah (permusuhan Muhammad

62 an-Nisa' 80

63 an-Nisa' 59

64 I'lamul Muwaqqi'inh Juz, 2, 282

65 Secara umum di dalam karya-karya Muhammad al-Ghazali tidak melakukan penelitian langsung terhadap hadits, yaitu: (1) melakukan al-I'tibaar, (2) meneliti pribadi periwayat (3) meneliti syudzuzd dan 'allah. Hal ini bisa dilihat dalam karya-karyanya, di antaranya al-Sunnah al-Nabawiyyah baina Ahl al-Fiqh wa al-Hadits dan Min Kunuz al-Sunnah; sebuah karya terkait langsung dengan studi hadits. Namun, untuk Fiqih al-Sirah, kajian sanad dan pen-takhrij-an yang dilakukan oleh Muhammad al-Ghazali lebih mendalam dibandingkandengan buku-buku yang lain,hal ini berkait dengan kritik yang dilakukan oleh Muhammad Nashr al-Din al-Albani yang melakukan kritik dan takhrij terhada hadits-hadits yang ada di dalam Fikih al-Sirah karya Muhammad al-Ghazali. 
al-Ghazali terhadap ahl al-hadits wa al-Jama'ah)66. Pada umumnya ulama Hadits mengharuskan kritik sanad terlebih dahulu, kemudian meneliti seatu lafadz dari berbagai matan Hadits yang semakna, setelah itu baru melangkah pada kritik matan dengna melihat kandungannya. Oleh karena itu peneliti atau pemahaman terhadap kandungan matan, baru dipandang urgen bila peneliti terhadap sanad menunjukkan benar-benar berkualitas shahih. Tegasnya, bila suatu Hadits sanadnya bertolak maka penelitian atau pemahaman tidak perlu lagi dilakukan. Peneliti sanad diperlukan sebagai upaya untuk membuktikan, bahwa Hadits atau informasi yang berkaitan dengan sunnah Nabi SAWmemiliki nilai kesejarahan yang otentik dan dapat ditulusuri hingga masa awal, karena informasi Hadits bukan karna rekaan atau karangan para ulama sebagai mana yang dituduh oleh sebagian orentalis.

Periwayatan sebelum Islam dikalahkan oleh orang Arab dan lainnya sebatas pada penyampaian kabar atau berita tanpa memperhatikan orang yang menyampaikan dan kebenaran berita itu. Namun ketika Islam datang dengan diutusnya Nabi Muhammad SAW. Yang membawa ajaran yang benar sangat menekankan pentingnya penelitain berita yang diterima. Hal ini sesuai dengan perintah dalam surat al-hujarat(49): 6:

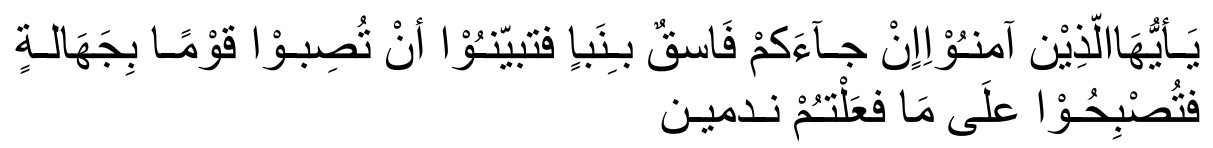

"Wahai orang-orang yang beriman, jika datang seorang yang fasik kepadamu membawa berita, maka tangguhkanlah (hingga kamu mengetahui kebenarannya) agar tidak menyebabkan kaum berada dalam kebodohan (kehancuran) sehingga kamu menyesal terhadap apa yang kamu lakukan"

Mengingat bahwa ajaran Nabi yang terangkum dalam sunnahnya merupakan salah satu sumber hukum Islam, maka sangat wajar jika umatIslam sangat besar perhatiannya terhadap periwayatan ini. Mereka berusaha menulusuri orang-orang yang mmenyampaikan atau meriwayatkan kabar yang konon dari Nabi, serta membahas kebenaran kabar itu. ${ }^{67}$

Salah satu keistimewaan periwayatan dalam Islam adalah mengharuskan adanya persambungan sanad, mulai dari

66 Kata pengantar buku terj Rabi' bin Hadi al-Madkhali, XVII-XVIII.

${ }^{67}$ Salamah Noorhidayati, Kritik Teks Hadits, (Yogyakarta: Teras, 2009), 18.

Abdul Basid Kritik Terhadap Metode 
periwayatan mulai dari mukharrijsampai kepada periwayat tingkat sahabat yang meneriam hadits yang bersangkutan dari Nabi SAW. Yang semua itu harus diterima dari para periwayatan yang âdildan dhâbit. Sedangkan telah disebut diatas, bahwa periwayatan yang ada pada umat lainnya adalah sebatas pada periwayatan, yaitu menerima dan menyampaikan berita tanpa ada persyaratan yang mengikat. 68

Hal ini ditemukan, misalnya, pada periwayatan yang ada pada umat yahudi Sanad yang menghubungkan kepada Nabi Musa as. Terdapat keterputusan baik di awal, tengah maupun akhir periwayat. Bahkan keterputusan itu ada pada sekitar tiga puluh orang (masa atau tabaqah), atau bersambung hanya sampai pada Syam'un atau semasanya. demikain juga pada kaum Nasrani. Di sana tidak ditemukan adanya sanadyang menghubungkannya sampai pada Nabi Isa as. Periwayatannya banyak mengalami keterputusan, dan yang dimungkinkan bersambung hanya sanad pada periwayatan tentang haramnya talaq. Itu pun masih belum disepakati. Demikian juga pada Injil yang diduga mengandung keraguan yang besar. ${ }^{69}$

Sanad atau isnad diyakini sebagai jalan yang meyakinkan dalam rangka penerimaan hadits. Beberapa pernyataan hadits berikut ini menjadi bukti atas pernyataan pentingnya isnad ini. Diantaranya adalah Muhammad bin Hatim al-Mudaffar yang mengatakan bahwa sesungguhnya Allah memuliakan dan melebihkan umat Islam atas umat lainnya dari sisi isnad, yang tidak ada umat sebelum dan sesudahnya yang mempunyai isnadyang bersambung. Bahkan menurut al-Qadi'iyad, isnad adalah poros (madar)hadits, yang dengannya akan diketahui kebenaran Hadits itu. 'Abd Allah bin al-Mubarak menyatakan:

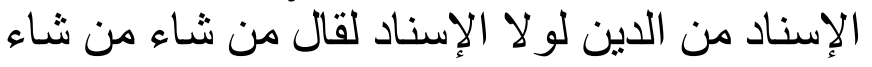

Bahwa isnad, merupakan bagian dari agama, jka tanpa isnad, mereka akan berkata sesuka hatinya. ${ }^{70}$

Ibnu shirin mengatakan:

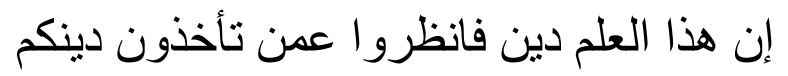

68 Ibid, 19.

69 Muhammad Jamal ad-Din al-Qasimiy, Qawaid at-Tahdits min Funum Mustalah al-Hadits, ([t.k] Isa al-Habiy al-Halabiy wa Syirkah 1961), 201.

70 Abu al-fadl 'iyad bin Musa al-Yahsubiy, al-Ilma' ila Ma'rifah ushul ar-riwayah wa taqyid as-sima' (Mesir: Dar al-Turats, 1970), 194 
Bahwa isnad merupakan bagian dari agama, maka perhatikanlah dari siapa kalian mengambilnya.

Oleh karenanya, maka penelitian terhadap sumber berita mutlak diperlukan. ${ }^{71}$

\section{Kesimpulan}

Dari penjelasan yang penulis ulas di atas dapat diterik kesimpulan sebagai berikut: Bahwa metode Muhammad al-Ghazali di dalam memahami Hadits meliputi langkah-langkah sebagai berikut:

a. Pengujian dalam al-Qur'an,

Menurut Muhammad al-Ghazali, pengujian dengan al-Qur'an dimaksudkan agar setiap Hadits bisa dipahami dengan menggunakan kerangka makna-makna yang ditunjukkan oleh alQur'an, pesan-pesan, semangat nilai-nilai yang dikandung dalam al-Qur'an, dan juga menganalogikakan (qiyas) dengan hukumhukum al-Qur'an.

b. Pengujian dengan Hadits

Ini dimaksudkan bahwa hukum agama tidak boleh di ambil dari suatu Hadits yang terpisah dengan lainnya, tetapi harus dikaitkan dengan Hadits lainnya dan dikomparasikan dengan apa yang ditunjukkan oleh al-Qur'an.

c. Pengujian dengan fakta Historis

Ada Hadits yang memiliki hubungan sinergis dengan data sejarah. Jika terdapat kecocokan dengan fakta sejarah, maka hal demikian akan menjadikan Hadits tersebut memiliki standart validitas yang kokoh, demikian juga sebaliknya jika bertentangan dengan sejarah, maka salah satu keduanya diragukan kebenarannya.

d. Pengujian dengan kebenaran ilmiah

Pengujian ini bisa diartikan bahwa setiap kandungan Hadits tidak boleh bertentangan dengan teori ilmu pengetahuan atau penemuan ilmiah dan juga memenuhi rasa keadilan dengan hak asasi manusia.

Kemudian kritik penulis atas pemikiran metode Muhammad al-Ghazali dalam memahami Hadits Nabi Muhammad Saw adalah sebagai berikut; Muhammad al-Ghazali tidak mau mempergunakan hadits âhâd dalam menetapkan akidah. Menurut Muhammad alGhazali, masalah akidah harus berdasarkan keyakinan bukan dugaan dan, sesuatu yang dhanni tidak layak untuk diamalkan dan

${ }^{71}$ Salamah Noorhidayati, 21

Abdul Basid Kritik Terhadap Metode 
dijadikan hukum. Penelitian hadis pada kritik matan. kajian Muhammad al-Ghazali terhadap Hadits Nabi menitik beratkan pada kritik matan, dalam arti mengkaji otentisitas sebuah matan hadis dan mengungkap makna (memahami hadis Nabi).

\section{Daftar Pustaka}

al Qardhawi, Yusuf. Syeikh Al Gazali Kamâ 'Araftuhu. (Beirut: Dâr Syurûq, 2000)

al-Bukhari, Abu Abdullah Muhammad Ibn Isma'il al-Ju'fi. Sahih alBukhari, Jilid VII. (Damaskus: Dar al-Kutub al-Islamiyah, t.t.) al-Maliki, Muhammad Alawi. Ilmu Ushul al-Hadit. (Yogyakarta: Pustaka Pelajar, 2012)

al-Naisaburi, Muslim Ibn Hajjaj Abu al-Hasan al-Qusyairi. Sahih Muslim, Jilid III. (Beirut: Dar Ihya' al-Turath al'Arabi, t.t.)

al-Nasa'ie, Abu Abdurrahman Muhammad Ibn Syu'ib Ibn Ali alKhurasani. Sunan al-Nasa'ie, Jilid VII. (Kairo: Dar al-Kutub alIslamiyah, t.t.)

al-Nasyasyar, Ali Samil. Nas'at al-Fikr al-Falsafi al-Islam. Jilid I. (Kairo: Dar-al-Ma`arif, 1981)

al-Qaradhawi, Yusuf. Al-Sunnah Mashdaran li al-Ma'rifah wa alHadharah, (Kairo: Dar al-Shuruq, 1997)

al-Qaradhawi, Yusuf. Min Ajl al-Shahwah al-Rasyidah. (Mesir: Dar al-Wafa, 1995)

al-Qaradhawi, Yusuf. Syeikh al-Ghazali Kamâ 'Araftuhu. (Beirut: Dâr Syurûq, 2000)

al-Qasimiy, Muhammad Jamal ad-Din. Qawaid at-Tahdits min

Funum Mustalah al-Hadits. [t.k] Isa al-Habiy al-Halabiy wa Syirkah 1961)

al-Quzwini, Abu Abdullah Muhammad Ibn Yazid. Sunan Ibn Majah,

Jilid II. (Beirut: Dar Ihya' al-Kutub al-'Arabiyah, t.t.)

al-Quzwini, Ibnu Majah Abu Abdullah Muhammad Ibn Yazid. Sunan

Ibn Majah, Jilid I. (Beirut: Dar Ihya' al-Kutub al-'Arabiyah, t.t)

al-Shan'ani, Abu Bakar Abd al-Razzaq Ibn Hammam Ibn Nafi' al-

Humairi al-Yamani. Mushannaf Abd al-Razzaq al-San'ani, Jilid

IV. (Beirut: Al-Maktab al-Islami, t.t.)

al-Thayalisi, Abu Daud Sulaiman Ibn Daud Ibn Jarud. Musnad Abi

Daud al-Thayalisi, Jilid III. (Mesir: Dar Hijr, t.t.)

al-Turmudzi, Muhammad Ibn 'Isa Ibn Thaurah Ibn Musa Ibn

Dhahhak. Sunan al-Turmudzi, Jilid III. (Mesir: Muktabah Musthafa al-Halbah, t.t) 
al-Yahsubiy, Abu al-fadl 'iyad bin Musa. al-Ilma' ila Ma'rifah ushul ar-riwayah wa taqyid as-sima'. (Mesir: Dar al-Turats, 1970)

al-Zadi, Abu Daud Sulaiman Ibn Asy'asth Ibn Ishaq Ibn Basyir Ibn Syaddad ibn Amr. Sunan Abu Daud, Jilid IV. (Beirut: Dar alMakatabah al-'Ashriyah, t.t)

Briwn, Daniel W. Menyoal Relevansi Sunnah dalam Islam, terj. Jaziar Radianti dan Entin Sriani Muslim, (Bandung: Mizan, 2000)

Hakim, Maskur. Berialog dengan al-Qur'a, (Mizan, Bandung, 1996) Hidayat, Komaruddin. Memahami Bahasa Agama; Sebuah Kajian Tematik. (Jakarta: Paramadina, 1996)

Kaylani, Muhammad Said. al-Risalah al-Syafi'ie. (Mesir: Mustafa alBabi al-Halabim 1969)

Malkawi, Faith Hasan. al-'Atha'al-fikrli Syeikh Muhammad alGhazali, (Amman, 1996)

Mohammad, Hendri. Tokoh-tokoh Islam yang Berpengaruh Abad 20, (Jakarta: Gema Insani Press, 2006)

Myrsi, Muhammad Sa'id. 'Adzoma' al Islâm, terj. Khoirul Amru. (Pustaka Al Kautsar, 2007)

Noorhidayati, Salamah. Kritik Teks Hadits. (Yogyakarta: Teras, 2009)

Samsuddin, Zaenal Abidin. Ensiklopedi Penghujatan Terhadap Sunnah. (Jakarta: Pustaka Imam Abu Hanifah, 2007)

Shihab, M. Quraish. "kata pengantar" dalam Muhammad al-Ghazali Studi Kritik atas Hadits Nabi SAW. Antara Pemahaman Tekstual dan Kontestual, terj.Muhammad al-Baqir. (Bandung: Mizan, 1996)

Sucipto, Heri. Ensiklopedi Tokoh Islam, (Bandung: Hikmah, 2003)

Suryadi, Metode Kontemporer Memahami Hadits Nabi. (Yogyakarta: Teras, 2008)

Uwais, Abd al-halim. Syeikh Muhammad al-Ghazal, Marahil Azimmmah, (Kairo: al-Shahwah, 1993)

Wardi, Moh. "Interpretasi Kenabian (Peran Ganda Nabi Muhammad Sebagai Manusia Biasa dan Rasul)" Jurnal al-Ulum Jurnal Pemikiran dan Penelitian keislaman Universitas Islam Madura Vol. 2 No. 1 Juni 2015 